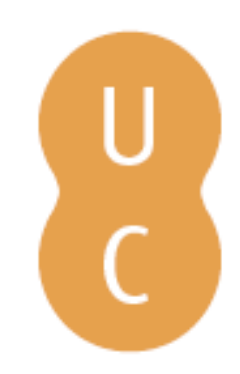

\title{
pombalina
}

\section{As plantas na obra poética de Camões (épica e lírica)}

\author{
Autor(es): $\quad$ Paiva, Jorge
}

Publicado por: UA Editora - Universidade de Aveiro; Imprensa da Universidade de

URL

persistente: URI:http://hdl.handle.net/10316.2/35691

DOI: $\quad$ DOI:http://dx.doi.org/10.14195/978-989-26-0941-6_5

Accessed : $\quad$ 26-Apr-2023 14:04:25

A navegação consulta e descarregamento dos títulos inseridos nas Bibliotecas Digitais UC Digitalis, UC Pombalina e UC Impactum, pressupõem a aceitação plena e sem reservas dos Termos e Condições de Uso destas Bibliotecas Digitais, disponíveis em https://digitalis.uc.pt/pt-pt/termos.

Conforme exposto nos referidos Termos e Condições de Uso, o descarregamento de títulos de acesso restrito requer uma licença válida de autorização devendo o utilizador aceder ao(s) documento(s) a partir de um endereço de IP da instituição detentora da supramencionada licença.

Ao utilizador é apenas permitido o descarregamento para uso pessoal, pelo que o emprego do(s) título(s) descarregado(s) para outro fim, designadamente comercial, carece de autorização do respetivo autor ou editor da obra.

Na medida em que todas as obras da UC Digitalis se encontram protegidas pelo Código do Direito de Autor e Direitos Conexos e demais legislação aplicável, toda a cópia, parcial ou total, deste documento, nos casos em que é legalmente admitida, deverá conter ou fazer-se acompanhar por este aviso.

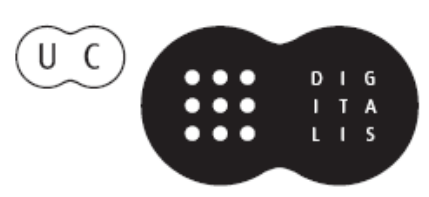




\section{HUMANISMO E CIÊNCIA Antiguidade e Renascimento}

António Manuel Lopes Andrade

Carlos de Miguel Mora

João Manuel Nunes Torrão
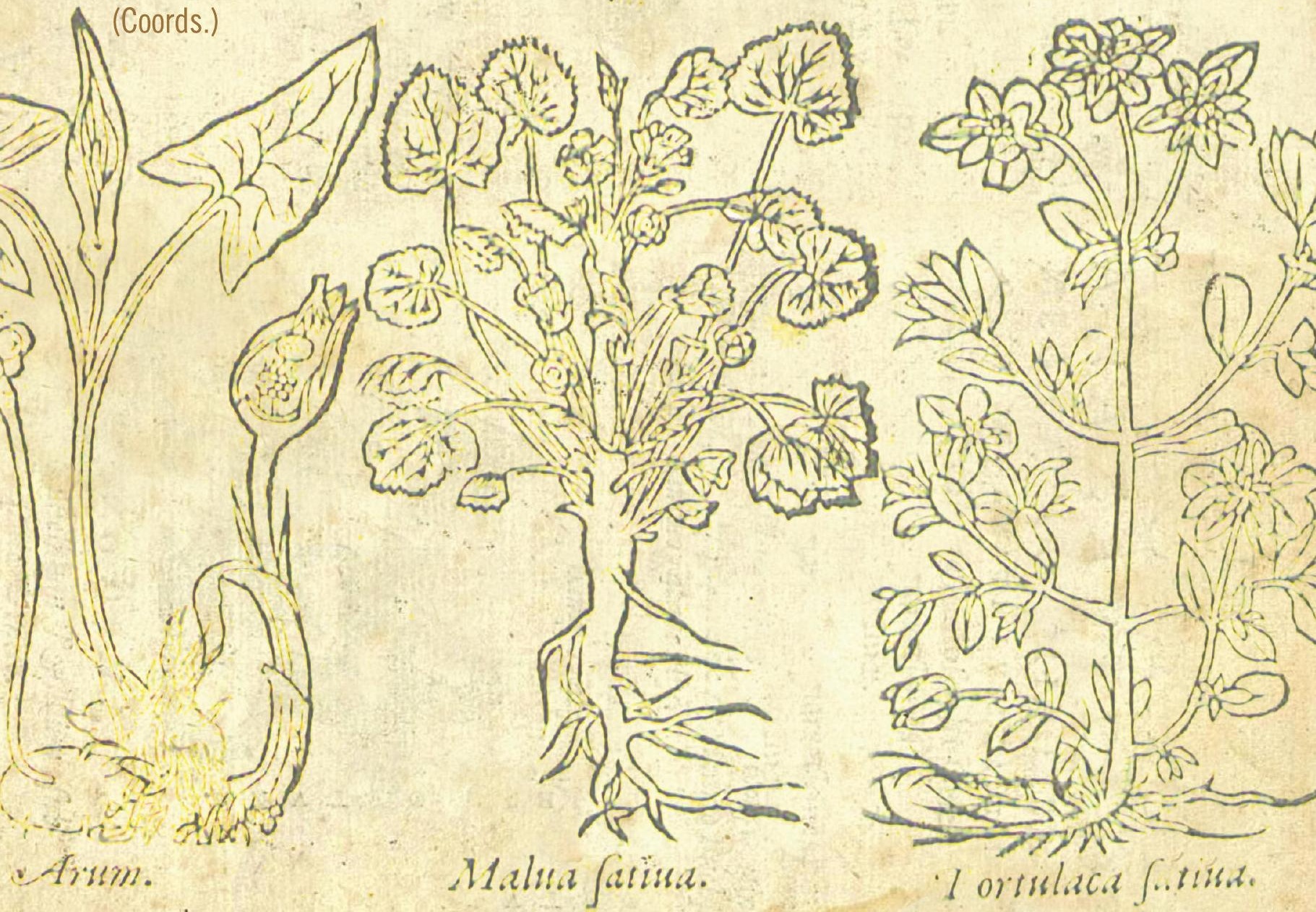

Aveiro I Coimbra I São Paulo 2015

UA Editora - Universidade de Aveiro I Imprensa da Universidade de Coimbra I Annablume 
Este volume resulta de várias iniciativas desenvolvidas no âmbito do projecto de I\&D "Dioscórides e o Humanismo Português: os Comentários de Amato Lusitano" (http://amatolusitano.web.ua.pt), recoIhendo contribuições de mais de duas dezenas de colaboradores, tanto de membros da equipa como de outros investigadores nacionais e estrangeiros. Entre os eventos que estiveram na origem deste livro destacam-se as três edições do Ciclo de Conferências promovido pelo projecto, realizadas entre 2010 e 2013, e sobretudo o Colóquio Internacional "Dioscórides e o Humanismo Português: os Comentários de Amato Lusitano", que decorreu no Departamento de Línguas e Culturas da Universidade de Aveiro, nos dias 21 e 22 de Novembro de 2013.

0 objectivo principal do projecto é a edição e tradução para português dos dois livros que Amato Lusitano dedicou ao comentário do tratado grego De materia medica de Dioscórides, ou seja, o Index Dioscoridis (Antuérpia, 1536) e as In Dioscoridlis Anazarbei de medica materia libros quinque... enarrationes (Veneza, 1553), estando contemplada, também, a tradução de mais duas obras directamente correlacionadas com os livros do médico português: a montante, a do próprio tratado grego de Dioscórides; a jusante, a do livro intitulado Apologia adversus Amathum Lusitanum (Veneza, 1558) de Pietro Andrea Mattioli.

OBRA PUBLICADA COM A COORDENAÇÃO

CIENTÍFICA DE:

Centro de Línguas, Literaturas e Culturas da Universidade de Aveiro

Centro de Estudos Clássicos e Humanísticos da Universidade de Coimbra

Cátedra de Estudos Sefarditas "Alberto

Benveniste" da Faculdade de Letras da Universidade de Lisboa 


\section{HUMANISMO E CIÊNCIA}

\section{Antiguidade e Renascimento}

ANTÓNIO MANUEL LOPES ANDRADE

CARLOS DE MIGUEL MORA

JOÃO MANUEL NUNES TORRÃO

(COORDS.)

AVEIRO • COIMBRA • SÃO PAULO

2015

UA EDITORA • UNIVERSIDADE DE AVEIRO

IMPRENSA DA UNIVERSIDADE DE COIMBRA

ANNABLUME 


\section{HUMANISMO E CIÊNCIA: Antiguidade e Renascimento}

\author{
EDIÇÃO

UA EDITORA • UNIVERSIDADE DE AVEIRO
IMPRENSA DA UNIVERSIDADE DE COIMBRA
ANNABLUME

ORGANIZAÇÃO E COORDENAÇÃO EDITORIAL ANTÓNIO MANUEL LOPES ANDRADE

CARLOS DE MIGUEL MORA

JOÃO MANUEL NUNES TORRÃO

\author{
DESIGN DA CAPA \\ MEIOKILO DESIGN STUDIO
}

DESIGN

CARLOS COSTA

IMPRESSÃO E ACABAMENTO

SERSILITO • MAIA

ISBN

UA • 978-972-789-434-5

IUC • 978-989-26-0940-9

\section{ISBN DIGITAL}

UA • 978-972-789-435-2

IUC • 978-989-26-0941-6

DOI

http://dx.doi.org/10.14195/ 978-989-26-0941-6

DEPÓSITO LEGAL 368241/13

TIRAGEM 500 Exemplares

(C) 2015

UA EDITORA • UNIVERSIDADE DE AVEIRO IMPRENSA DA UNIVERSIDADE DE COIMBRA

ANNABLUME

\section{COMISSÃO CIENTÍFICA}

António Manuel Lopes Andrade

Carlos de Miguel Mora

Delfim Ferreira Leão

Henrique Leitão

João Manuel Nunes Torrão

Maria de Fátima Reis

Maria do Céu Zambujo Fialho

Miguel Ángel González Manjarrés

\section{TEXTOS}

Adelino Cardoso

Ana Leonor Pereira

Ana Margarida Borges

António Guimarães Pinto

António Maria Martins Melo

Bernardo Mota

Carlos A. Martins de Jesus

Carlos de Miguel Mora

Cristina Santos Pinheiro

Donald Beecher

Emília Oliveira

Isabel Malaquias

James W. Nelson Novoa

Joana Mestre Costa

João Manuel Nunes Torrão

João Rui Pita

Jorge Paiva

José Sílvio Moreira Fernandes

Maria de Fátima Silva

Miguel Ángel González Manjarrés

Rui Manuel Loureiro

Telmo Corujo dos Reis

Teresa Nobre de Carvalho

Vinicije B. Lupis

Virgínia Soares Pereira 


\section{HUMANISMO E CIÊNCIA}

\section{Antiguidade e Renascimento}

ANTÓNIO MANUEL LOPES ANDRADE

CARLOS DE MIGUEL MORA

JOÃO MANUEL NUNES TORRÃO

(COORDS.)

AVEIRO • COIMBRA • SÃO PAULO

2015

UA EDITORA • UNIVERSIDADE DE AVEIRO

IMPRENSA DA UNIVERSIDADE DE COIMBRA

ANNABLUME 
OBRA PUBLICADA

COM A COORDENAÇÃO

CIENTÍFICA DE:

CENTRO DE LÍNGUAS,

LITERATURAS E CULTURAS DA

UNIVERSIDADE DE AVEIRO

CENTRO DE ESTUDOS

CLÁSSICOS E HUMANÍSTICOS DA

UNIVERSIDADE DE COIMBRA

CÁTEDRA DE ESTUDOS SEFARDITAS

"ALBERTO BENVENISTE"

DA FACULDADE DE LETRAS DA

UNIVERSIDADE DE LISBOA 


\section{SUMÁRIO}

PREFÁCIO

1.1 "Teofrasto, Tratado das plantas. No alvor de uma nova ciência" 13

Maria de Fátima Silva

1.2 "Francisco de Melo e os fragmentos de teoria óptica de Pierre Brissot" 21 Bernardo Mota

1.3 "Algumas reflexões sobre as pedras preciosas nos Colóquios dos simples de Garcia de Orta" 37 Rui Manuel Loureiro

1.4 "Estratégias, patronos e favores em Colóquios dos Simples de Garcia de Orta" 63 Teresa Nobre de Carvalho

1.5 "As plantas na obra poética de Camões (épica e lírica)" 95 Jorge Paiva

1.6 "Nicolás Monardes, John Frampton and the Medical Wonders of the New World" .141 Donald Beecher

1.7 "Literatura e Medicina: alguns textos de Justo Lípsio e de dois doutores Luís Nunes" 161 António Guimarães Pinto

1.8 "Ontologias e idiossincrasias dos Amantes, à luz da Archipathologia de Filipe Montalto" ...... 211 Joana Mestre Costa \& Adelino Cardoso

1.9 "Gabriel da Fonseca. A New Christian doctor in Bernini's Rome". .227 James W. Nelson Novoa 


\section{2) DIOSCÓRIDES E O HUMANISMO PORTUGUÊS: OS COMENTÁRIOS DE AMATO LUSITANO}

2.1 "Léxico científico português nos Comentários de Amato: antecedentes e receção"

Ana Margarida Borges

2.2 "Usos medicinais das plantas, em Amato Lusitano: o bálsamo"

António Maria Martins Melo

2.3 "Amato Lusitano e a importância da ilustração botânica no século xVI.

Em torno das edições lionesas das Enarrationes (1558)"

Carlos A. Martins de Jesus

2.4 "Sobre la identificación entre ébano y guayaco en una entrada

del Index Dioscoridis de Amato Lusitano".

Carlos de Miguel Mora

2.5 "Os partos distócicos em Amato Lusitano e em Rodrigo de Castro:

fontes, doutrinas e terapias greco-romanas"

\section{Cristina Santos Pinheiro}

2.6 "Do carvalho ao castanheiro: usos e propriedades medicinais

de fagáceas nas Enarrationes de Amato Lusitano".

Emília Oliveira

2.7 "O mundo mineral nos Comentários a Dioscórides de Amato Lusitano".

Isabel Malaquias \& Virgínia Soares Pereira

2.8 "Alguns comentários de Amato: entre a estranheza e a realidade"

João Manuel Nunes Torrão

2.9 "Caracterização e usos terapêuticos de produtos de origem marinha

nos Comentários de Amato Lusitano a Dioscórides"

José Sílvio Moreira Fernandes

2.10 "La mandrágora de Amato Lusitano: edición, traducción y anotación"

Miguel Ángel González Manjarrés

2.11 "O vinho e os vinhos - usos e virtudes de um dom dos deuses

nas Enarrationes de Amato Lusitano"

Telmo Corujo dos Reis

2.12 "Amatus Lusitanus e Didaco Pirro: due ebrei portoghesi

e cerchia umanistica di Dubrovnik" 481

Vinicije B. Lupis

2.13 "Estudos contemporâneos sobre Amato Lusitano". 513

João Rui Pita \& Ana Leonor Pereira 


\section{As plantas na obra poética de Camões (épica e lírica) ${ }^{1}$}

JORGE PAIVA ${ }^{2}$

\section{RESUMO:}

Na época camoniana, as plantas mais conhecidas e citadas na literatura, não eram tanto as plantas comestíveis ou ornamentais, mas mais as plantas medicinais. Como Os Lusíadas foram escritos, quase na totalidade, no Oriente e centrados nos Descobrimentos, têm como base plantas asiáticas, particularmente especiarias e medicinais; a Lírica como foi, maioritariamente, escrita em Portugal e centrada no amor e paixão, as plantas referidas são europeias e ornamentais. Numa e noutra obra o poeta raramente cita as mesmas plantas, mas quando isso acontece, fá-lo com significados diferentes. Como Camões viveu a sua grande paixão durante os treze anos que esteve em Coimbra (1531-1544), de onde partiu aos vinte anos, a maioria das plantas referidas na Lírica são plantas dos campos do Mondego. O mesmo acontece n'Os Lusíadas nos episódios da "Ilha dos Amores" (Canto IX, 18 - X, 95) e de "Inês de Castro" (Canto III, 118-135).

Num trabalho sucinto, não é possível abranger a vasta obra completa de Luís de Camões. Assim, abordaremos algumas das plantas mais invulgares referidas n'Os Lusíadas e praticamente todas as citadas na Lírica. Aliás, é n'Os Lusíadas que o poeta mais plantas menciona (cerca de cinco dezenas), na maioria asiáticas e aromáticas. Na Lírica refere muito menos espécies de plantas (cerca de três dezenas e meia), maioritariamente, europeias campestres e ornamentais.

\section{PALAVRAS-CHAVE:}

Camões; poesia (Épica e Lírica); plantas.

1 Este trabalho foi desenvolvido no âmbito do projecto de I\&D "Dioscórides e o Humanismo Português: os Comentários de Amato Lusitano" (http://amatolusitano.web.ua.pt) do Centro de Línguas, Literaturas e Culturas da Universidade de Aveiro, financiado por Fundos FEDER através do Programa Operacional Factores de Competitividade - COMPETE e por Fundos Nacionais através da FCT - Fundação para a Ciência e a Tecnologia, no âmbito do projecto FCOMP-01-0124-FEDER-009102.

2 Centro de Ecologia Funcional da Universidade de Coimbra: jaropa@bot.uc.pt. 


\begin{abstract}
:
In Camões' time, the better known plants in literature were not necessarily the edible ones, but were rather the medicinal ones. The spices, being aromatic plants, are all included in the edible or medicinal plants. So, the study of plants referred by Camões must be based on the botanic knowledge of the 16th century, mainly on medicinal plants. Furthermore, as Os Lusíadas were written, almost in their totality, in the East and centered in the Discoveries, they have their basis on the Asian spices; in the lyric work, as it was mainly written in Portugal and centered in love and passion, the plants referred are European and ornamental. On both works the poet rarely refers to the same plant, but when it happens, he does it with different meanings. As Camões lived his great passion during the thirteen years he lived in Coimbra (1531-1544), which he left when he was twenty years old, the majority of plants referred in his lyric poems are plants from the Mondego river fields. The same happens in the "Ilha dos Amores" of Os Lusíadas (Canto IX, $18-95 ; X, 1-143)$

In a concise work, it is not possible to include the vast work of Luís de Camões. So, we will approach some of the most uncommon plants referred in Os Lusiadas and practically all the lyric ones. Moreover, it is in Os Lusíadas that the poet refers to more plants (about fifty), mainly Asian and aromatic. In the lyric the poet mentions less species of plants (about thirty five), mainly European, from the countryside or ornamental.
\end{abstract}

\title{
KEYWORDS:
}

Camões; poetry (epic and lyric); plants. 


\section{PREÂMBULO}

Como se sabe, Luís Vaz de Camóes teve uma vida muito atribulada e escassamente documentada, pois segundo H. Saraiva "Documentos autênticos sobre a vida de Camôes, documentos originais e indiscutidos, daqueles que ninguém póe em dúvida, sabe-se de sete: o perdão do rei pela cutilada na cabeça de um empregado do Paço em dia do Corpo de Deus de 1552, o privilégio da publicação d'Os Lusíadas e o alvará da tença de 15000 réis durante três anos; os outros quatro são prorrogaçóes do prazo da tença."3

Por haver tão restrita documentação fidedigna sobre a vida de Camôes, actualmente não só se sabe muito pouco sobre factos reais, como também o que se pode elaborar são meras conjecturas conseguidas de interpretaçóes retiradas da sua obra poética (Épica e Lírica).

Era filho de Simão Vaz de Camóes e Ana de Sá e Macedo, mas pouco ou praticamente nada se sabe sobre a mãe. Náo se conhece ao certo a localidade e dia do nascimento; apenas se sabe que foi em 1524. Também não se conhece com exactidão a data da morte. Faleceu na capital do país, em 1580, muito provavelmente a 10 de Junho.

Sabe-se que o poeta viveu treze anos em Coimbra (1531 a 1544), portanto dos sete aos vinte anos, onde, inicialmente, esteve ao cuidado do seu tio Bento Camóes, prior do Convento de Santa Cruz e chanceler da Universidade, que o recomendou, em 1535, para aio (escudeiro) de Francisco de Noronha e Violante de Andrade, acabados de casar, ele com trinta anos e ela com treze anos. Em 1540, quando Camóes tinha dezasseis anos e Violante dezoito, Francisco de Noronha vai para França como embaixador, até 1544. Nesse mesmo ano, o casal vai para Lisboa, tal como Camóes. Em 1547 vai para Ceuta (desterrado?), regressando a Lisboa cego de um olho. Em 1550 vai para algures no Ribatejo, para um povoado junto às margens do Tejo. Regressa a Lisboa, e em 1552 é preso no dia do Corpo de Deus, indo para a prisão do Tronco. Em 1553 parte para Goa, em cumprimento da pena a que fora condenado, sendo, novamente preso em Goa. Esteve em Macau e sofreu um naufrágio no Estuário do rio Mekong. Em Dezembro de 1567, parte de Goa e, depois de uma estada na Ilha de Moçambique (1568-1570), chega a Cascais a 7 de Abril de 1570. Em 1572 é editada, em Lisboa, a 1. a edição d'Os Lusíadas, tendo sido censor o Padre Bartolomeu Ferreira e Inquisidor-geral o Cardeal D. Henrique. Morre em Lisboa em 1580 (10 de Junho?).

3 Cf. J. H. Saraiva, Vida ignorada de Camões. Mem Martins, Publicações Europa-América, ${ }^{2} 1982$, p. 17 (Estudos, Ensaios e Documentos 141). 


\section{INTRODUÇÃO}

Camóes, conhecia, seguramente, não só obras gregas sobre plantas, particularmente o tratado De materia medica (64 d.C.) de Pedânio Dioscórides (40-90 d.C.), como também os Coloquios dos simples, e drogas he cousas mediçinais da India (1563) de Garcia de Orta, por quem acalentava uma afectuosa amizade e admiração.

Aliás, a biblioteca do Convento de Santa Cruz, onde seu tio Bento Camóes era prior, era muito rica em obras da Antiguidade Clássica, que, muito provavelmente, o poeta consultou. Como Camóes refere muitas plantas europeias citadas por autores gregos e poetas anteriores a ele, alguns autores (ex. Joaquim Vieira Natividade, 1970 e Augusta F. G. Ventura, 1930-1943) admitem que Camóes refere essas plantas com o mesmo significado utilizado por esses poetas. $\mathrm{Na}$ minha opinião, Camões não foi um "plagiador". É natural que tenha utilizado algumas plantas já referidas por outros, particularmente as ornamentais, mas utilizou-as com significado bem diferente. $\mathrm{O}$ facto de Camóes referir muitas plantas nunca citadas por poetas anteriores, particularmente n'Os Lusíadas, onde refere muitas espécies asiáticas, constitui o melhor testemunho que o grande poeta não copiou ninguém.

Apesar de se saber isso, não é fácil determinar com exactidão todas as plantas referidas por Camóes na sua obra poética (Épica e Lírica), pois a maioria das vezes refere-as não só de forma poética, como também utilizando a sua admirável arte de derivar (ele próprio afirma que os seus versos são 'derivações') com extraordinários malabarismos linguísticos.

Num trabalho sucinto não é possível explanar toda a flora da vasta obra poética de Luís de Camóes. Assim, abordaremos algumas das plantas mais invulgares referidas n'Os Lusíadas e as plantas que o poeta utilizou na Lírica, comparando as duas floras (Épica e Lírica) e explicitando as semelhanças e diferenças no significado que o poeta lhes confere n'Os Lusiadas e na poesia lírica. Aliás, é n’Os Lusiadas que o poeta mais plantas menciona (cerca de cinco dezenas), na maioria asiáticas e aromáticas. Na Lírica refere muito menos espécies de plantas (cerca de três dezenas e meia), maioritariamente, europeias campestres e ornamentais, particularmente as flores destas. Na parte final deste trabalho, apresentamos uma lista de nomes científicos das plantas mencionadas na Épica e outra das mencionadas na Lírica.

$\mathrm{Na}$ época camoniana, as plantas mais conhecidas e citadas na literatura não eram tanto as plantas comestíveis, mas mais as plantas medicinais. As especiarias, como todas são plantas aromáticas, estão incluídas tanto numas como noutras. Por isso, o estudo das plantas citadas por Camóes deve ser feito com base nos conhecimentos botânicos do século XVI, maioritariamente circunscritos às plantas medicinais e campestres.

Comecemos por referir que quando se formou a nossa espécie, praticamente, a totalidade das outras espécies animais que hoje existem já habitavam o Globo Terrestre. Por isso, a espécie humana (Homo sapiens L.) aprendeu muito com a Natureza e com os outros animais. Assim, 
copiamos os outros animais na alimentação e, também, no uso de muitas das plantas medicinais que ainda hoje utilizamos. É disto exemplo, uma planta que em S. Tomé é designada por "aliba-cassô", que quer dizer planta do cão, que é uma erva, Eleusine indica (L.) Gaertn. [na Europa a grama-dente-de-cão é também uma erva da mesma família (Gramíneas), a Cynodon dactylon (L.) Pesrs.], que os cães comem quando têm desarranjos intestinais. Capacitando-se disso, os santomenses, quando têm disenterias tratam-se com infusóes dessa planta. Claro que também aprendemos com os outros animais a utilização das plantas tóxicas, como, por exemplo, a noz-vómica (Strychnos nux-vomica L.), cujas sementes contêm estricnina, sendo, por isso, que os símios não comem o fruto desta espécie de Strychnos, mas sim os frutos das espécies de Strychnos que não têm estricnina. É um fenómeno idêntico ao que acontece com os cogumelos.

A nossa espécie utiliza plantas alimentares e medicinais praticamente desde que apareceu na Terra. Conhecem-se documentos sobre plantas medicinais há mais de cinco mil anos, como são os documentados sistemas médicos chineses e o "ayurvédico" indiano. Antes da fabricação dos medicamentos pela indústria farmacêutica, que não tem mais do que século e meio, as enfermidades eram tratadas directamente com mezinhas das plantas ou dos animais. Foi, por isso, que a 5 de Outubro de 1773, o Marquês de Pombal escreveu ao então Reitor da Universidade de Coimbra (D. Francisco de Lemos), rejeitando o grandioso plano para o Jardim Botânico de Coimbra, que este lhe enviara, dizendo:

\begin{abstract}
Debaixo d'estas regulares medidas deve, V. Ex. ${ }^{a}$ fazer delinear outro plano, reduzido somente ao numero de hervas medicinais que são indispensáveis para os exercícios botânicos, e necessarias para se darem aos estudantes as instruçôes precisas para que não ignorem esta parte da medicina.... ${ }^{4}$
\end{abstract}

O Marquês não queria um Jardim Botânico sumptuoso, ornamental e muito dispendioso, mas um Jardim simples e fundamentalmente com plantas medicinais.

O tratado De materia medica (64 d.C.) de Pedânio Dioscórides (40-90 d.C.), célebre físico (cirurgião) grego, considerado uma das obras mais antigas sobre plantas, onde se descrevem os atributos (cerca de 1000) de cerca de 600 espécies de plantas, foi o guia da medicina ocidental durante mais de 16 séculos, o que implicou um reduzidíssimo progresso da fitoterapia, pois além da versão grega original, houve também traduçóes para várias línguas, algumas com erros graves que se repetiram durante séculos. Muitas publicaçóes (mesmo actuais) sobre plantas medicinais limitaram-se a parafrasear a obra de Dioscórides. Aliás, a maioria dos nomes utilizados por Dioscórides tinha sido utilizada por Hipócrates (ca. 460-370 a.C.) no seu catálogo De herbis com mais de 230 nomes de plantas, mais tarde descritas por Cratevas (120-60 a.C.)

4 Cf. J. Palva, "Jardins Botânicos. Sua origem e importância", Munda 2 (1981), pp. 35-44. 
em Rhizotomikon, assim como por Teofrasto (370-285 a.C.) no livro Xvi da sua Historia plantarum. O manuscrito de Rhizotomikon perdeu-se e, segundo alguns autores 5 , foi a fonte principal do "Herbário" de Séxtio Níger, no qual Plínio e Dioscórides basearam os seus trabalhos.

Portanto, a descrição dos atributos medicinais das plantas europeias e, em parte, asiática, é conhecida, está documentada e registada por escrito há muitos séculos.

Como se referiu, a obra de Dioscórides foi não só traduzida para diversos idiomas, entre os quais o latim, como até aumentada, alterada e iconografada, não correspondendo alguns dos desenhos às descriçóes dioscoridianas. Foi na obra de Dioscórides que não só Garcia de Orta, como também João Rodrigues de Castelo Branco, o Amato Lusitano, basearam os seus conhecimentos fitoterápicos, tendo, no entanto, Garcia de Orta acrescentado os conhecimentos da medicina "ayurvédica" indiana. Aliás, o título da obra de Amato Lusitano (In Dioscoridis Anazarbei De Materia Medica... Enarrationes Eruditissimae) é bem elucidativo de que assim foi.

Estas obras e outras sobre produtos naturais da Ásia, tal como o livro de Duarte Barbosa (1516) ${ }^{6}$ são cruciais para uma determinação, o mais exacta possível, das plantas referidas por Camóes, particularmente n'Os Lusíadas, escrito, quase na totalidade, durante a sua estada no Oriente.

Camóes acalentava uma afectuosa admiração por Garcia de Orta, resultante das relaçóes pessoais que mantiveram na Índia, a tal ponto que conseguiu do vice-rei D. Francisco de Sousa Coutinho, conde do Redondo, patrocínio para a publicação da célebre obra do eminente médico naturalista (Coloquios dos simples, e drogas he cousas mediçinais da Índia, 1563). O poeta conhecia certamente o Horto de Garcia de Orta, como é dedutível pela estrofe da ode ao Conde do Redondo, Viso-Rey da India, o primeiro poema a ver letra de forma, que antecede o texto da

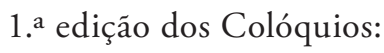

\footnotetext{
Olhai que em vossos annos

Produze hua Orta insigne varias ervas.

Nos campos indianos:

Has quaes, aquellas doutas e protervas

Medea, e Circe nunca conheceram.

Posto que as leis da Magica excederam.
}

5 A. G. MORTON, History of Botanical Science, an account of the development of Botany from ancient times to the present day. London, Academic Press, 1981.

6 Livro de Duarte Barbosa. Lisboa, Academia Real das Sciencias, 1813. 
Como já referimos, as plantas citadas n'Os Lusíadas são maioritariamente asiáticas e especiarias e na Lírica plantas dos campos do Mondego e Tejo. Por essa razáo, para determinados poemas polémicos, por haver (ou ter havido) críticos literários que os consideram camonianos e outros não, as plantas citadas n'Os Lusíadas e na Lírica poderão auxiliar na autoria camoniana ou não. É, por exemplo, o caso do "Vergel de Amor". Nesta poesia, citam-se, por vezes, muitas plantas por estrofe, o que não é característico de Camóes e mencionam-se muitas plantas que não encontramos citadas em toda a obra poética indubitavelmente camoniana, como, por exemplo, as boas-noites (Mirabilis jalapa L.), nativas do Peru e não conhecidas na Europa na época camoniana e o girassol (Helianthus annuus L.), também nativo do Continente Americano; assim como plantas dos montes, como as giestas (Cytisus spp.), e os rosmaninhos (Lavandula spp.).

\section{PLANTAS D'OS LUSÍADAS}

O coco das Maldivas ou coco-do-mar é um bom exemplo de plantas não dioscoridianas tratadas por Garcia de Orta nos seus Colóquios (Colóquio Décimo Sexto) e referida por Luís de Camóes (Canto X), tendo este utilizado a sua, já referida, admirável arte de derivar com extraordinários malabarismos linguísticos, quando menciona este coco na Lírica.

O coco-do-mar não é mais do que o fruto de uma palmeira (coqueiro) endémica (planta nativa apenas de determinado local ou região) da República das Seychelles. Por isso, é também, e mais correctamente, conhecido por coco das Seychelles. Por causa da forma do caroço, é também conhecido por coco-das-nádegas, coco-indecente, coco-gémeo ou coco-duplo e outros nomes, como coco-de-Salomão, coco-real, coco-da-escravatura e muitos outros epítetos vernáculos em idiomas asiáticos. Os frutos das palmeiras são cocos (drupas, como são os pêssegos, as ameixas, as cerejas, etc.) com uma camada fibrosa (geralmente oleosa) que envolve um caroço, no qual está a semente (amêndoa). Antes da descoberta do caminho marítimo para a Índia (1497-98), este coco não era conhecido na Europa, mas era já famoso na Ásia, onde conheciam apenas o caroço, que consideravam, erroneamente, como uma semente, sem nunca terem visto a palmeira que o produzia (assim o diz Garcia de Orta no referido colóquio "que nunqua pessoa alguma vio a arvore que dá estes coquos, senão o que o mar deita de si;”). É o maior $(30-50$ x 25-28 cm) e mais pesado $(15-20 \mathrm{~kg}$ ) caroço (portanto, também a maior e mais pesada semente) do Globo Terrestre. Por ser uma semente tão pesada, nem o respectivo coco, nem o caroço, flutuam facilmente, não sendo, portanto, transportados, com viabilidade, pelas correntes marítimas, como acontece com o fruto do coqueiro (Cocos nucifera L.). No entanto, como a parede do caroço é muito dura e dificilmente permeável, o caroço, depois de seco ou 
da perda da massa interna (embrião e albúmen, portanto a semente propriamente dita) fica muito mais leve e já é flutuante e transportável pelas correntes marítimas. Era assim, sem poder germinativo, que chegava às ilhas Maldivas (assim diz Ruano nos Colóquios "que dizem das Maldivas") e às costas da Índia, Indonésia e respectivas ilhas, onde os primeiros europeus deram conta da fama deste invulgar caroço, devido à sugestiva forma que apresenta (lembra formas anatómicas femininas).

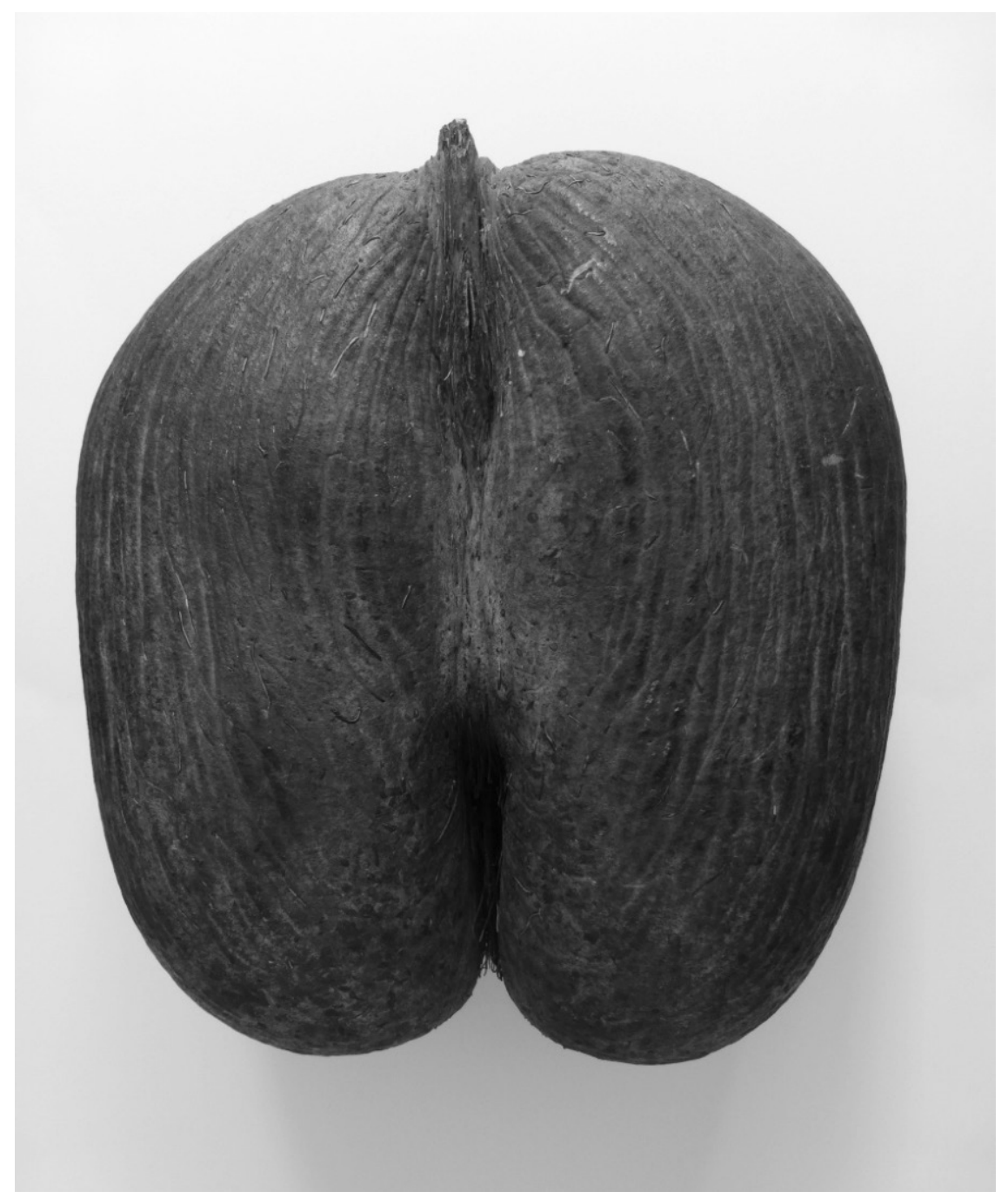

Figura 1 - Coco das Maldivas [Lodoicea maldivica (J. F. Gmel.) Pers.]. Museu da Ciência (Universidade de Coimbra) 
Por isso este caroço era, erroneamente, conhecido como coco das Maldivas, a tal ponto que o botânico que primeiro nomeou cientificamente a palmeira (Johann Friedrich Gmelin), em 1796, designou-a por Cocos maldivica, baseando-se apenas no caroço, pois não conhecia a planta. Quando se soube que afinal a palmeira não era nativa das Maldivas, mas das Seychelles, Jacques Julien Houtton de la Billardière, em 1801 (comunicação oral na Academia das Ciências Francesa, em Paris, mas só publicada validamente em 1807) ${ }^{7}$, designou-a por Lodoicea sechellarum. Porém, a primeira descrição científica da planta, feita por Pierre Sonnerat, é anterior (lida numa sessão da Academia das Ciências de França em 1773 e publicada em 1776) ${ }^{8}$ à de Billardière (1807), mas Sonnerat não lhe concedeu nenhum nome em latim. O género Lodoicea foi criado por Philbert Commerson (de Lodoicus, forma latinizada de Louis em homenagem ao rei Luís xv de França, pois as Seychelles eram, na época, uma colónia francesa) e descrito por Augustin Pyramus de Candolle em 1800. Neste género, mono-específico (só tem uma espécie), a planta teve várias designaçôes (L. callipyge Comm. ex J. St.-Hil.; L. humilis Pharm. ex Wehmer; L. maldavica Pers. ex H. Wendl.; L. seychellarum Labill. e L. sonnerati Baill.), mas o nome válido, segundo as Regras Internacionais de Nomenclatura Botânica, é Lodoicea maldivica (J. F. Gmel.) Pers.

Como os povos asiáticos nunca tinham visto a palmeira produtora de um coco tão grande e tão invulgar, consideravam (mais tarde, os navegadores europeus também) que era produzido por um coqueiro que vegetava nas profundezas do mar. Por outro lado, como o caroço tem uma forma bilobada ("que vem pegados dous em hum”, segundo Garcia de Orta nos Colóquios) que se assemelha às ancas e zona púbica da mulher, foi, por isso, considerado afrodisíaco e, como era muitíssimo raro e extremamente apreciado, era excessivamente dispendioso. Aliás, ainda hoje é caro e não é fácil adquiri-lo. Assim, nas ilhas Maldivas, arquipélago onde vinham, por vezes, caroços dar à costa, o direito de propriedade de todos os cocos-do-mar que apareciam nas praias destas ilhas, era pertença dos soberanos das mesmas, e qualquer pessoa que não entregasse algum desses achados era condenada à morte ou era-lhe sentenciada a ablação das mãos. Desta maneira, os primeiros exploradores europeus ao trazerem para a Europa este valioso caroço (geralmente considerado semente) enalteceram-lhe não só extraordinárias qualidades afrodisíacas, como também atributos místicos e medicinais (como o diz Ruano mais adiante "Dixeramme que a rainha, nossa senhora, mandava todo los anos por este coquo, e lho levam de cá; e por tanto não me negueis ser pêra a peçonha bom;"). Foi, por toda essa reputação que o coco tinha, que Rudolfo II dos Habsburgos (Imperador do Santo Império Romano), ofereceu, em vão, 4000 florins de ouro (uma fortuna para a época) por um coco desses, que

7 "Sur le Cocotier de Mer des Maldives", Annales du Muséum National d'Histoire Naturelle 9 (1807), pp. 140-145.

8 Voyage a la Nouvelle Guinée. Paris, Ruault, 1776. 
pertencia ao almirante holandês Wolfert Hermanssen, que o tinha recebido como presente do Sultão de Bantam (regiáo da ilha de Java), por ter defendido a capital do sultanato de um ataque da Armada Portuguesa, sob o comando de André Fortunato de Mendonça, em 16029. É por isso que há, actualmente, em museus europeus alguns destes caroços ocos, cobertos a ouro ou prata e ornamentados exteriormente com figuras decorativas, que serviam, geralmente, de vasilhas ou copos.

A primeira referência feita por um europeu a este coco e respectiva palmeira, aliás extraordinariamente fantasiosa, é de António Pigafetta, em 1519-22, quando relatou a passagem da frota de Fernão de Magalhães pelos mares da China e Sião, na sua viagem de circum-navegação. Aliás, a mais absurda, fantasiosa e romântica publicação sobre esta planta e respectivos atributos, foi feita pelo general inglês Charles Gordon, que visitou as Seychelles em 1881 e considerou que o Vallée de Mai (actualmente Parque Nacional na ilha Praslin, sendo a área onde vegeta naturalmente a maior quantidade de palmeiras do coco-do-mar) era o Jardim de Éden, onde vegetava a "Árvore da Ciência, do Bem e do Mal" (Lodoicea maldivica) e a "Árvore da vida" [a árvore-do-pão, Artocarpus insignis (Parkinson ex F.A. Zorn) Fosberg]. A fantasia foi tal que este general até se esqueceu que a árvore-do-pão foi introduzida nas Seychelles, pois é nativa da Malásia. Depois do italiano Pigafetta, os portugueses foram, naturalmente, outros europeus a referirem o coco-do-mar, como João de Barros, em 1553, que, como era habitual na época, considerou que o "pomo maior do que o coco" vinha de uma árvore que "nascia em algumas partes debaixo da água salgada”.

Outros europeus se seguiram nas referências a este legendário coco, como o holandês Jan Huygen van Linschoten que refere, em 1610, que o rei das Maldivas oferecia de presente este coco a soberanos locais e estrangeiros pelas suas propriedades contra peçonhas; o "fisico" holandês Antgers Cluyt (Augerius Clutius) publicou em Amesterdão (1634) a primeira monografia sobre o coco-do-mar, em que refere uma dúzia de doenças e outras enfermidades para as quais o coco era um bom remédio; o comerciante francês Pyrard de Laval que, por naufrágio em 1602, viveu vários anos numa das ilhas Maldivas, refere, mais uma vez, que este coco, que os nativos consideravam um tesouro pelas suas propriedades medicinais, era produzido por algumas árvores submarinas. Finalmente, o botânico Georg Eberhard Rumphius publicou um exaustivo estudo sobre o coco-do-mar, em 1750, em que descreve um conjunto de lendas sobre este coco e refere que os marinheiros chineses, malaios e indonésios acreditavam que as folhas do coqueiro-do-mar apareciam, por vezes, sobre o mar. Refere também que os soberanos das regióes onde o referido coco aparecia no litoral marítimo, não permitiam que se partissem os caroços, pois serravam-nos para fazerem caixas ou vasilhas e respectivas tampas para guardarem os ingredientes de mascar,

9 A.-A. Fauvel, "Le Cocotier de mer des lles Seychelles (Lodoicea Sechellarum)", Annales du Musée Colonial de Marseille, Sér. 3, 1 (1915), pp. 169-307. 
porque acreditavam que estes produtos, assim como a água potável, quando armazenados nestas caixas (vasilhas), adquiriam virtudes medicinais ou curativas para uma grande quantidade de enfermidades. Rumphius foi o primeiro botânico a admitir que a palmeira produtora de tais cocos crescia no Oceano Índico Ocidental.

Foi só em 1768, cerca de 26 anos depois de os franceses terem aportado às Seychelles [159 anos depois de os ingleses as terem descoberto (já eram conhecidas dos árabes, pelo menos, desde o ano 916)] que Brayer du Barré, um engenheiro francês integrado na expedição comandada por Nicholas Marion Dufresne (com a nau La Diguffe e a escuna La Curieuse), que foi da ilha Maurícia para as Seychelles, reconheceu a palmeira do coco-do-mar na ilha Praslin (ilha de Palma, na época). Atónito, não querendo acreditar no que os seus olhos viam, colheu cerca de uma trintena de cocos que levou para o botânico francês Pierre Poivre que se encontrava na ilha Maurícia (na época ilha de França) mais a Sul. Este pediu ao abade Alexis Rochon que trouxesse das Seychelles jovens coqueiros do coco-do-mar para a ilha Maurícia. A partir daqui, por iniciativa do Capitão Duchemin, que tinha participado na expedição de Marion Dufresne às Seychelles e que estava ao corrente da descoberta de Barré, deslocou-se à ilha de Praslin na nau L'Heureuse Marie, carregando-a de cocos que comercializou no mercado asiático, tendo, assim, descido, drasticamente e de modo definitivo, o valor económico deste fabuloso coco.

Apesar disso, esta palmeira e o respectivo coco não perderam a reputação, não só de virtudes afrodisíacas (além do caroço cluniforme, a forma da inflorescência masculina também se assemelha ao phallus humano e a fase inicial da germinação do caroço é cópulo-sugestiva), como também medicinais e místicas.

Assim, a colheita dos cocos foi tão intensiva que a planta, actualmente, apenas cresce, como espontânea, nas encostas e vales do interior de duas das 19 ilhas do Arquipélago das Seychelles [na ilha Praslin (Parque Nacional de Vallée de Mai, com cerca de 5000 exemplares, pois 59\% das árvores do Parque são Lodoicea maldivica) e na vizinha e pequena ilha Curieuse (primeiramente ilha Rouge)]. Além destes locais onde é nativa e espontânea, está cultivada em Jardins Botânicos, particularmente tropicais, onde a vimos nalguns, como no Jardin du Roi e Botanical Gardens em Victoria (capital da República das Seychelles na ilha Mahé), Pamplemousses Botanical Gardens (ilha Maurícia), Peradeniya Botanical Gardens em Kandy (Sri Lanka), Bogor Botanical Garden em Bogor (Indonésia), Singapore Botanical Gardens (Singapura), Darwin Botanic Gardens em Darwin (Austrália) e, em estufa aquecida (Palm House) dos Royal Botanic Gardens em Kew (Inglaterra).

Actualmente, nas Seychelles, a colheita e comercialização destes cocos é estritamente controlada pelo Estado, sendo uma importante fonte de receita local a venda aos turistas de peças de artesanato fabricadas com folhas, troncos e cocos desta palmeira. Porém, a população nativa não usufrui apenas da comercialização e da fama afrodisíaca e virtudes medicinais e místicas deste coco, pois o grande limbo flabeliforme das folhas é utilizado para cobertura das habitações, 
para fabrico de esteiras, leques, cestos, caixas, estojos, chapéus, ramos de noiva e outros artigos de artesanato; a madeira e pecíolos foliares para tabiques, paliçadas e bebedouros para o gado; os caroços para pratos, vasilhas, copos, caixas, artigos de adorno e produção de marfim vegetal; os pêlos da parte inferior dos pecíolos das folhas jovens para encher almofadas e travesseiros. Dos cerca de 3000 destes cocos que são colhidos anualmente nas Seychelles (colheita controlada pelo Estado), apenas um pequeno número é consumido verde. Normalmente congelam a amêndoa (semente), para depois a servirem aos turistas como guloseima e, até, para produzirem uma bebida alcoólica (17\%), licorosa, que, como não podia deixar de ser, tem a designação de licor de coco d'amour e as garrafas têm a forma sugestiva do caroço.

Garcia de Orta, nos seus Colóquios, refere que o coco das Maldivas provinha de palmeiras que haviam sido submergidas quando as ilhas Maldivas se separaram do Continente Asiático por uma grande inundação e que a amêndoa deste coco era um excelente remédio. É importante referir que Garcia de Orta o cita como "um excelente remédio" e nunca faz qualquer alusão às apregoadas propriedades afrodisíacas deste coco. É fundamental não esquecer que nessa altura não só a Inquisição era poderosa, como também Garcia de Orta tinha que ter extremo cuidado, pois, sendo cristão-novo, era alvo de perseguição do Santo Ofício pela sua origem judaica.

Talvez pelo misticismo que conferiam a este coco, a palmeira "marinha" é uma das plantas que Luís de Camôes refere n'Os Lusíadas (Canto X, 136) ${ }^{10}$, também, cuidadosamente, sem qualquer alusão às célebres propriedades afrodisíacas do coco, pelas razóes que já referimos (Inquisição e Corte). É também importante referir que não só toda a obra de Camóes foi escrita entre 1540 e 1580, período de violentas perseguições aos Judeus; como também alguns autores modernos ${ }^{11}$ admitem uma origem bastarda e judaica de Camóes.

\footnotetext{
Nas Ilhas de Maldiva nace a pranta

No profundo das agoas soberana

Cujo pomo contra o veneno urgente

He tido por Antidoto excelente.
}

Camões também o refere na Lírica, obra centrada no amor e paixão, e aí utiliza eficazmente os seus, já referidos, malabarismos lexicológicos, para não ter qualquer consequência desagradável por parte dos censores e do Inquisidor-geral (Cardeal D. Henrique). É uma das poucas plantas asiáticas que Camóes refere tanto na Épica, como na Lírica.

10 As citações dos versos camonianos feitas ao longo deste trabalho foram feitas a partir do texto fixado por Hernâni Cidade nas obras completas de Luís de Camões (I- Os Lusíadas; II-Rimas; III- Lírica).

11 Cf. J. H. Saraiva, Vida ignorada de Camões, op. cit. 
Assim, no soneto que, segundo J. H. Saraiva, é dedicado à recuperaçáo do valimento de D. António Pinheiro, bispo de Miranda, que fora obrigado, pelo Rei, a renunciar à diocese de Ceuta, tendo readquirido todo o valimento durante o reinado do cardeal D. Henrique, Camóes, na nossa opinião, utiliza aqui, de modo extraordinário, os seus malabarismos para exaltar a fama afrodisíaca deste coco:

Depois que viu Cibele o corpo humano

Do formoso Átis, seu verde pinheiro,

Em piedade o vão furor primeiro

Convertido, chorou seu grave dano.

E, fazendo a sua dor ilustre engano,

A Júpiter pediu que o verdadeiro

Preço da nobre palma e do loureiro

Ao seu pinheiro desse, soberano.

Mais lhe concede o filho poderoso

Que as estrelas, subindo, tocar possa,

Vendo os segredos lá do céu superno.

Oh! ditoso pinheiro! Oh! mais ditoso

Quem se vir coroar da folha vossa,

Cantando à vossa sombra verso eterno.

Ao ler-se com atenção repara-se que Camões refere as ditas propriedades afrodisíacas do coco. O "pinheiro" do formoso Átis estava com "grave dano". Aqui Camóes está a indicar que o órgão sexual de Átis fora "convertido" (deixara de ser "fálico", isto é, viril). Então, Cibele pediu a Júpiter que "o verdadeiro preço da nobre palma e do loureiro ao seu pinheiro desse, soberano". Isto é, que conferisse virilidade ao dito órgão de Átis. No que foi atendida Cibele, como se pode deduzir das últimas estrofes deste soneto "Oh! Ditoso pinheiro! Oh! Mais ditoso quem se vir coroar da folha vossa, cantando à vossa sombra verso eterno".

O mesmo se pode dizer na Redondilha "Carta a uma dama":

Da palma se escreve e canta

Ser tão dura e tão forçosa,

Que pena não a quebranta,

Mas antes, de presunçosa,

Com ele mais se levanta.

Co'o peso do mal que dais,

A constância que em mim vejo 
Não somente ma dobrais,

Mas dobra-se meu desejo,

Com que entáo vos quero mais.

Salientamos as palavras mais elucidativas do malabarismo camoniano: "Da palma se escreve e canta ser tão dura e tâo forçosa que pena não a quebranta, mas antes, de presunçosa". $\mathrm{Na}$ nossa opinião, aqui refere os atributos afrodisíacos do coco. Depois "Com ele mais se levanta". Este "ele" é o órgão sexual masculino. E depois "Co'o peso do mal que dais"... "Não somente ma dobrais". O que é que se dobra sem poder erectivo devido ao desgosto amoroso?

Aliás, já Cidália Alves dos Santos ${ }^{12}$ refere estas subtilezas do poeta na habilidosa evocação erótica da exibição e ocultamento do corpo da deusa Diana, utilizando plantas em metáforas com sentido erótico (hera) e ao referir o foco do desejo sexual, os lábios vulvares, como sendo "os roxos lírios" (Canto II, 36, 37):

Os crespos fios de ouro se esparziam

Pelo colo, que a neve escurecia;

Andando, as lácteas tetas lhe tremiam,

Com quem Amor brincava e não se via;

Da alva petrina flamas lhe saíam,

Onde o Menino as almas acendia;

Pelas lisas colunas lhe trepavam

Desejos, que como hera se enrolavam.

C'um delgado cendal as partes cobre,

De quem vergonha é natural reparo,

Porém nem tudo esconde nem descobre,

O véu, dos roxos lírios pouco avaro;

Mas, para que o desejo acenda e dobre,

Lhe põe diante aquele objeto raro.

Já se sentem no céu, por toda a parte,

Ciúmes em Vulcano, amor em Marte.

12 "Camões y Góngora; una lectura del erotismo en Los Lusíadas y en la Fábula de Polifemo y Galatea", Castilla. Estudios de Literatura 28-29 (2003-2004), pp. 23-46. 
Camóes, n’Os Lusiadas, refere ainda outras palmeiras. Uma no Canto I, 45, 46:

Eis aparecem logo em companhia

Uns pequenos batéis, que vêm daquela

Que mais chegada à terra parecia,

Cortando o largo mar com larga vela.

A gente se alvoroça, e de alegria,

Não sabe mais que olhar a causa dela.

-"Que gente será esta?” (em si diziam)

"Que costumes, que leis, que rei teriam?"

"As embarcações eram na maneira

Mui velozes, estreitas e compridas;

As velas com que vêm eram de esteira,

Dũas folhas de palma bem tecidas;

A gente da cor era verdadeira

Que Fáeton, nas terras acendidas,

Ao mundo deu, de ousado e náo prudente

(O Pado o sabe, e Lampetusa o sente).

Estas esteiras de folha de palma deviam ser feitas, muito provavelmente, das folhas flabeliformes de Borassus aethiopum Mart., uma palmeira relativamente comum nas baixas planícies do litoral central de Moçambique. Actualmente, as velas dessas embarcaçóes (pequenos batéis, os sambucos, de influência indo-árabe, de 2 velas e semelhantes às nossas caravelas) são feitas de "estopa" de sacos de farinha ou de pano. $\mathrm{Na}$ área de Matibane (cerca da ilha de Moçambique) são feitas das folhas flabeliformes de outras espécies de palmeiras pertencentes ao género Hyphaene, também comuns nessas regióes. Francisco Manuel de Mello (Conde de Ficalho, $1890)^{13}$ sugere que a palma usada para as velas pudesse também ser das folhas flabeliformes de Borassus flabellifer L., uma palmeira da Índia, utilizada para esse fim no litoral indiano. $\mathrm{Na}$ realidade, sabe-se que ainda há cerca de um século, os indianos, aproveitando os ventos das monções, iam em barcos à vela, aos mangais do litoral tanzaniano e moçambicano colher madeira para fabrico de habitaçôes. Desta maneira, poderiam ter fornecido, por permuta, esteiras da palmeira indiana aos pescadores moçambicanos. É uma hipótese, mas pouco plausível. $\mathrm{Na}$ nossa opiniấo, os africanos copiaram as velas indianas, utilizando as palmeiras nativas de folhas flabeliformes (Borassus aethiopum Mart.) como as da palmeira indiana (Borassus flabellifer L.).

13 Conde de Ficalmo, Flora dos Lusiadas. Lisboa, Academia Real das Sciencias, 1880. 
Outra palmeira citada por Camóes (Canto VIII, 24 e Canto X, 42) é a tamareira (Phoenix dactylifera L.), já referida pelos "físicos" gregos, nos textos bíblicos, corânicos e por Garcia de Orta (Colóquio Quinquagesimo Terceiro), pela sua importância alimentar e religiosa:

\author{
A Dom Mateus, o Bispo de Lisboa, \\ Que a coroa de palma ali coroa. (VIII, 24) \\ "Que gloriosas palmas tecer vejo, \\ Com que Vitória a fronte lhe coroa, \\ Quando, sem sombra vã de medo ou pejo, \\ Toma a ilha ilustradíssima de Goa, (X, 42)
}

Como não podia deixar de ser, Camões refere também o aloé (Canto X, 137). Mas cita o aloé da ilha Socotra (Iémen) e não o Aloe vera (L.) Burm. f., o mais conhecido e citado aloé, desde a Antiguidade Grega e Tempos Bíblicos.

Verás defronte estar do Roxo Estreito

Socotorá, co’o amaro aloés famosa;

Este aloé de Socotra, já é referido por Aristóteles, que pretendeu que o Imperador Alexandre conquistasse esta ilha, por saber que ali havia muito aloé, de que necessitava para tratar as feridas dos soldados, pois é um bom cicatrizante. Na realidade, o Imperador, ao regressar da Índia, desterrou os habitantes da ilha de Socotra, fundando ali uma colónia grega para cultivarem os aloés.

Esta planta tem sido erradamente identificada como Aloe socotrina Lam. (ex Ficalho, 1890), aliás, um nome latino inexistente, por suporem tratar-se do Aloe succotrina Lam., que não é nativo de Socotra.

Mas, além de se confundir Aloe vera (L.) Burm.f. com os aloés da ilha de Socotra (Aloe perryi Bak. e Aloe forbesii Bak. f.), comercialmente utilizados para extrair a socotrina (tâyef, na ilha; saber ou sabr ou sabbara em árabe), também se tem confundido com Aloe succotrina Lam., nativo da província do Cabo da África do Sul, não só por se julgar que o restritivo específico é referente a Socotra, como também porque Philip Miller, em 1758, lhe chamou Aloe vera Mill. (non L.). O epíteto succotrina nada tem a ver com a ilha de Socotra; o termo deriva de sucocitrina, produto químico do suco das folhas deste aloé originário da África do Sul.

Desde que o frade franciscano Romano Zago, um brasileiro de São Francisco de Assis (Rio Grande do Sul, Brasil), na altura professor de Filosofia e de Latim no Convento de San Salvatore, em Jerusalém, deu a sua primeira grande entrevista à revista argentina "Florecillas de Tierra Santa”, por ter curado a leucemia de Geraldito, uma criança argentina, o cancro de Linda, irmã de 
uma amiga da freira Silvana, da Comunidade de Aida (Israel) e o cancro de Frei Rafael Caputo, director de uma Escola eclesiástica na Terra Santa, há cerca de uma dúzia de anos que se criou a panaceia do Aloe vera. Seguiram-se muitas mais entrevistas, conferências e curas milagrosas, tendo até o frade Romano Zago vindo a Portugal onde proferiu conferências no Porto, Coimbra, Odivelas e Lisboa, tendo sido entrevistado pelas emissoras de Rádio e Televisão.

A panaceia foi tal que em 1995-1996, quase desapareceram os aloés, que até não são Aloe vera (L.) Burm.f., mas, geralmente, Aloe arborescens Mill., dos jardins públicos de Portugal, pois as pessoas, tomadas de uma loucura colectiva, utilizavam o suco das folhas de qualquer aloé, na tentativa de tratarem qualquer tipo de doença e, até, apenas como uma espécie de vacina, mesmo sem estarem doentes. Formavam-se filas à porta do Convento dos Franciscanos em Lisboa, para compra do remédio milagroso. Não sei se esta romaria já parou, passados que são mais de uma dúzia de anos de muitas desilusões. Publicaram-se muitos artigos, plenos de erros, particularmente na identificação das espécies de Aloe, até recentemente, em revistas de divulgação e em livros sobre plantas medicinais, sendo alguns desses textos de autoria de pessoas com grandes responsabilidades, por efectuarem investigação científica com plantas medicinais.

Nessa altura alertei para o logro em que as pessoas tinham caído, através de entrevistas e vários artigos de divulgação e na televisão, mas sem grandes resultados. Indivíduos sem escrúpulos continuam a vender gato por lebre, comercializando outras espécies de aloés como sendo Aloe vera (L.) Burm.f., que é muito pouco cultivado nos jardins de Portugal. Apenas tenho conhecimento de exploraçôes agrícolas extensivas de Aloe vera (L.) Burm.f. em Portugal, no Algarve (concelhos de Portimão e de Vila do Bispo).

Como os aloés têm folhas suculentas (crassas), erroneamente, com muita frequência, designam-nos por cactos, um lapso "crasso". Os verdadeiros cactos, são, na realidade, plantas crassas (suculentas), geralmente afilas (sem folhas) e com espinhos, que constituem a família das Cactáceas, com cerca de 2000 espécies nativas das estepes americanas (América do Norte, Central e do Sul; apenas um género fora da América), tendo sido introduzidos, por cultivo, noutras regióes do Globo, onde algumas espécies se naturalizaram e adaptaram tão bem que se tornaram invasoras, como aconteceu, por exemplo, com a figueira-da-índia [Opuntia ficus -indica (L.) Mill.], uma cactácea originária do México e não da Índia, como erroneamente o epíteto específico leva a crer.

Há cerca de 350 espécies de aloés, das quais quase metade (140) é nativa de África, sendo as restantes de Madagascar, Socotra, Região Mediterrânica, Arábia, Índia e China.

O verdadeiro Aloe vera (L.) Burm.f. é nativo do Nordeste de África e, muito provavelmente, também da Arábia. É utilizado como medicinal há milhares de anos, havendo testemunhos disso desde 1500 anos a. C., no Egipto ("Papyrus Ebers", Universidade de Leipzig), referindo alguns autores que o encanto e beleza de Cleópatra se devia ao uso do "gel" de aloé. 
O Aloe vera foi muito apreciado, como planta medicinal, pelos "físicos" gregos, como refere Hipócrates (ca. 460-370 a. C.) no seu De herbis, Teofrasto (370-285 a. C.) em Historia plantarum e descrito por Dioscórides em De materia medica. O Aloe vera (L.) Burm.f., actualmente, está naturalizado na Região Mediterrânica, Macaronésia (Madeira, Açores, Canárias e Cabo Verde), América Central e do Sul.

Sendo utilizado desde antes de Cristo, não admira que o Aloe vera (L.) Burm.f. seja referido nos textos bíblicos. Mas, nem todas as referências a aloés nas diversas ediçôes da Bíblia são verdadeiros aloés. Os aloés citados no Antigo Testamento (Salmos 45:9; Provérbios 7:17; Cântico dos Cânticos 4:14) são plantas que não pertencem ao género Aloe. Aí são referidas como plantas aromáticas, conjuntamente com a mirra [Commiphora myrrha (Nees) Engl.], a caneleira do Ceilão (Cinnamomum vera Nees) e a caneleira da China [Cinnamomum cassia (L.) J.Presl], que até são referidas como árvores (Cântico dos Cânticos 4:14) e o Aloe vera é uma erva não aromática. Esse aloé citado no Antigo Testamento é uma árvore muito aromática, a Aquilaria malaccensis Lam. (ahaloth, em Hebraico), a que os gregos chamam xylaloe e a que Garcia de Orta dedica um Colóquio (Trigesimo; Do linaloes) e também chama agalugem e que, portanto, Camões também refere n'Os Lusiadas (Canto X, 129).

\footnotetext{
"Vês: corre a costa que Champá se chama,

Cuja mata é do pau cheiroso ornada;
}

Por isso, quando traduziram os textos em hebraico do Antigo Testamento para grego, à ahaloth chamaram (muito bem) xylaloe. Ao traduzirem a Bíblia do grego para latim, traduziram (erroneamente) xylaloe para aloe. Aloe vera é uma erva, não aromática, com propriedades cicatrizantes, e é o aloé referido no Novo Testamento (João 19:39). Aqui, refere-se que envolveram o corpo de Jesus com ligaduras e uma mistura de mirra [Commiphora myrrha (Nees) Engl.] e aloés [cerca de 100 libras (45-50 kg), levadas por Nicodemos], para o sepultarem, como era costume entre os judeus. Estes aloés são o Aloe vera (L.) Burm.f. ou, pouco provavelmente, Aloe perryi Bak. e Aloe forbesii Bak. f., nativos da ilha de Socotra e muito confundidos com o Aloe vera. Actualmente, ainda persiste esse hábito de envolverem (embalsamarem) os mortos com aloés e outras plantas (particularmente aromáticas, pois muitas delas são anti-sépticas), não só em Israel, como também entre os árabes.

Após os descobrimentos, o Aloe vera foi introduzido no Novo Mundo, provavelmente pelos espanhóis, a partir de plantas levadas das Canárias. Naturalizou-se rapidamente nas Índias Ocidentais (Barbados, Jamaica, Antígua, Porto Rico), na América Central (México, Nicarágua) e na América do Sul (Peru, Bolívia, Venezuela). Por isso, Philip Miller (1768) designou por Aloe barbadensis Mill., uma planta supostamente nativa da ilha dos Barbados, que não é mais do que o Aloe vera (L.) Burm.f. 
Infelizmente, essa confusão persiste ainda hoje, com a agravante de andarem a chamar Aloe barbadensis Mill. a um Aloe que não é o verdadeiro Aloe barbadensis Mill., isto é, que não é Aloe vera (L.) Burm.f. O pior é que essas confusôes até aparecem em livros sobre plantas medicinais de autores com grandes responsabilidades, por fazerem investigação cientifica na área química das plantas medicinais. Não admira, pois, que nesses livros se apresentem produtos químicos diferentes para o Aloe barbadensis Mill e para o Aloe vera (L.) Burm.f., pois Aloe barbadensis Mill. que referem não é o autêntico e, portanto, não é o Aloe vera (L.) Burm.f. ${ }^{14}$

$\mathrm{Na}$ África do Sul, começou, há já alguns anos, a utilizar-se como fonte comercial de produtos dos aloés, uma planta muito comum nos jardins desse país, o Aloe arborescens Mill. Inicialmente extraiam os produtos químicos do Aloe vera (L.) Burm.f., mas como o Aloe arborescens Mill. é não só largamente cultivado como ornamental, como também é nativo e bastante comum na Natureza daquele país, passaram a utilizar, para a obtenção do suco de aloé, este último em vez do Aloe vera (L.) Burm.f., que ali tinham que cultivar. Porém, não só a composição química do suco dos dois aloés é diferente, como também, como é evidente, as qualidades terapêuticas das duas espécies sejam igualmente diversas.

Aloe arborescens Mill. é nativo do sudoeste e sul de África (Zimbabwe, Malawy, Moçambique e África do Sul) e é muito utilizado como ornamental nas regiões temperadas do Globo, estando, actualmente, naturalizado em muitas regióes fora da respectiva área nativa, como no sudoeste da Região Mediterrânica (Sul de França, Espanha e Portugal).

Em Portugal (e não só), infelizmente, muita gente e herbanários sem escrúpulos, utilizam o Aloe arborescens Mill., como fonte do suco de aloé, para o comercializarem como se fosse o suco do verdadeiro Aloe vera (L.) Burm.f.

Gilbert Reynolds (1895-1967) foi o mais eminente especialista do género Aloe, tendo publicado duas excelentes monografias $\left(1950\right.$ e 1966) ${ }^{15}$, profusamente ilustradas com fotografias e desenhos a cores, pois ele observou vivas a maioria das espécies, muitas delas cultivadas nos jardins das suas residências na África do Sul e na Suazilândia. Este autor e Robert Compton (1886-1979), que foi director do Jardim Botânico de Kirstenbosch (África do Sul), durante a década de 70 do século passado, alertaram para o facto de se estar a comercializar gato por lebre, elucidando que o suco das folhas das duas espécies tinha composição química diferente e, portanto, propriedades medicinais também distintas. O suco das folhas dos aloés é um bom cicatrizante, virtude que nós próprios já constatamos e que é conhecida há muitos séculos, tanto que, na Antiga Grécia, Aristóteles utilizou as folhas de Aloe vera (L.) Burm.f. para tratamento dos ferimentos dos soldados gregos. Porém, enquanto o suco das folhas do Aloe arborescens Mill.

14 A. Proença da Cunha, A. P. da Silva, O. R. Roque, Plantas e produtos vegetais em fitoterapia. Lisboa, Fundação Calouste Gulbenkian, 2003.

15 G. W. ReYnolds, The Aloes of South Africa. Johannesburg, Aloes of South Africa Book Fund, 1950; Idem, The Aloes of Tropical Africa and Madagascar. Mbabane, The Trustees. The Aloes Book Fund, 1966. 
é eficaz no tratamento de queimaduras (até as devidas a Raios X), o do Aloe vera (L.) Burm.f. não o é. Como na literatura fitoterápica se têm confundido várias espécies de Aloe, têm sido atribuídas ao Aloe vera virtudes que não possui.

Encontram-se referências ao uso do Aloe vera no tratamento de cancros, mas, pessoalmente, não conheço nenhum trabalho científico demonstrativo de tal atributo desta planta. Por outro lado, também não conheço nenhum caso de cura de cancro de doentes que se trataram exclusivamente com o suco "milagroso", parando com todos os outros tratamentos que seguiam por indicação médica, como a quimioterapia e a radioterapia. Antes pelo contrário, conheci pessoas cancerosas, tanto em Portugal, como no estrangeiro, que se trataram com Aloe vera e morreram de cancro.

$\mathrm{Na}$ referida literatura encontram-se mencionadas muitas outras virtudes dos aloés, além das que acabamos de referir, tais como colagogas, emenagogas, vermífugas, repelentes de insectos, estimulantes, laxativas, no tratamento da meningite, conjuntivite crónica, blefarite, obstipação, ictiose, várias outras doenças cutâneas, úlceras e até, inimaginável, no tratamento da esterilidade. Enfim, os aloés curam todos os males!...A panaceia foi (e continua a ser) de tal ordem que, em 1996, até houve quem tivesse a desfaçatez de propor os aloés como as Plantas do Ano em Portugal.

Há imensas falsidades difundidas acerca destas plantas, como também, na grande maioria dos casos, se está a vender como Aloe vera (L.) Burm.f., outras espécies de Aloe, particularmente o Aloe arborescens Mill., que é o mais comummente cultivado nos nossos jardins, o que é grave, pois o suco deste último é laxativo e pode provocar reacçóes alérgicas.

Se o Aloe vera ou qualquer outra planta tivesse as propriedades oncológicas propagadas, as grandes multinacionais da indústria farmacêutica não deixavam de explorar tal filão, nem o deixavam entregue em mãos alheias. Aliás, a indústria sem escrúpulos, já explora este filão, pois encontram-se à venda produtos de cosmética (cremes, sabonetes, loções, águas de colónia, etc... até loções para a queda do cabelo...) fabricados por multinacionais como sendo à base de Aloe vera, não o sendo, na maioria dos casos.

O pior é que até na indústria alimentar já estão à venda alimentos com "Aloe vera". Considero um crime para a saúde pública, permitir-se a venda dos iogurtes com "Aloe vera". Não sei se têm suco do Aloe vera, mas se o têm, é criminoso permitir-se que crianças comam um alimento com um cicatrizante poderoso, sem terem qualquer infecção, fazendo com que o organismo da criança perca resistências a futuras infecçóes. A Organização Mundial de Saúde (OMS) e o Instituto Nacional de Farmácia e do Medicamento (INFARMED) não permitem a comercialização de medicamentos não comprovados cientificamente. Por isso, não há à venda medicamentos à base do "Aloe vera" para tratamento de cancros. A indústria de cosméticos é uma indústria sem regras que explora a vaidade das pessoas. A indústria de plantas medicinais e os "herbanários" também não têm regras e exploram a 
ingenuidade das pessoas. Mas a indústria alimentar é controlada pela Agência de Segurança Alimentar e Económica (ASAE). Por isso, não se entende como se encontram à venda iogurtes com "Aloe vera".

O verdadeiro Aloe vera (L.) Burm.f. distingue-se bem de todos os outros Aloe com os quais o confundem, deliberadamente ou não, pois tem flores amarelas e os outros não. Aloe perryi Bak. e Aloe forbesii Bak.f., nativos da ilha Socotra, têm flores cor de salmão, que amarelecem depois da antese (abertura das flores), amarelecendo da base para o cimo da inflorescência; Aloe succotrina Lam., da África do Sul, tem flores avermelhadas e Aloe arborescens Mill., do sudoeste e sul de África, tem flores escarlate. Além disso, o hábito das plantas e as inflorescências também são diferentes. Geralmente Aloe arborescens Mill. e Aloe succotrina Lam. são subarbustivos e têm as inflorescências simples (pedúnculos não ramificados), ao passo que Aloe vera (L.) Burm.f., Aloe perryi Bak. e Aloe forbesii Bak.f. são herbáceos e com as inflorescências 2-3-ramificadas. Na presença unicamente das folhas não é fácil distingui-los, daí as trapaças de muitos indivíduos gananciosos e sem escrúpulos.

A fundamental razão que levou os portugueses a desejarem a posse de Timor, uma das denominadas ilhas de sândalo, foi a riqueza das suas florestas em sândalo (Santalum album L.), uma árvore de madeira considerada preciosa, aromática e muito utilizada medicinalmente desde tempos remotos. Actualmente, ainda é muito apreciada e utilizada, particularmente nos países asiáticos, para o fabrico de produtos cosméticos aromatizados (sabonetes, loções, etc.). Garcia de Orta refere-a várias vezes nos seus Colóquios, assim como Camões n’Os Lusíadas (Canto X, 134):

"Ali também Timor, que o lenho manda

Sândalo, salutífero e cheiroso;

Durante a ocupação indonésia de Timor, as florestas de sândalo foram praticamente dizimadas, decorrendo, actualmente, um programa de cooperação portuguesa com reprodução de sândalos em viveiros. Não é fácil a produção de sândalo para reflorestação, por ser uma planta semi-parasita, necessitando, por isso de um hospedeiro lenhoso.

Finalmente, referimos apenas mais uma planta camoniana d'Os Lusíadas, não só por ser aromática e medicinal, como também e principalmente por ser do seu nome latino (Laurus nobilis L.) [laurus; em grego $\Delta \alpha ́ \varphi v \eta$ (dafne)] que derivou o termo vencedor laureado. A planta não só foi consagrada ao deus Apolo, como também era com ramos de loureiro que se coroavam os Imperadores romanos e os vencedores. Assim, tal como os ramos de oliveira simbolizam paz, os ramos de louro (Laurus nobilis L.) simbolizam vitória ou vencedor. É por isso que se representa quase sempre a figura de Camóes com uma coroa de louros. É com essa simbologia que o poeta o refere n'Os Lusíadas (Canto III, 97): 
Quanto pode de Atenas desejar-se

Tudo o soberbo Apolo aqui reserva;

Aqui as capelas dã tecidos de ouro,

Do bácaro e do sempre verde louro.

Claro que é também uma planta referida pelo poeta na Lírica, mas com outro sentido, tanto no já referido soneto:

Depois que viu Cibele o corpo humano

Do formoso Átis, seu verde pinheiro,

Em piedade o vão furor primeiro

Convertido, chorou seu grave dano.

$E$, fazendo a sua dor ilustre engano,

A Júpiter pediu que o verdadeiro

Preço da nobre palma e do loureiro

Ao seu pinheiro desse, soberano.

Como na ode a D. Manuel de Portugal:

A quem daráo de Pindo as moradoras,

Táo doutas como belas,

Florescentes capelas

Do triunfante louro ou mirto verde,

Da gloriosa palma, que não perde

A presunção sublime,

Nem por força de peso algum se oprime?

Referimos algumas plantas invulgares e algumas curiosidades das plantas mencionadas por Camôes n'Os Lusíadas, mas muito mais há a dizer. Porém, resultaria um trabalho extremamente longo e preferimos apresentar uma lista com todas as plantas citadas na obra épica camoniana.

\section{PLANTAS DA LÍRICA}

$\mathrm{Na}$ Lírica, Camóes cita principalmente e como era previsível, flores e plantas campestres portuguesas, com a excepção de duas plantas asiáticas, o coco das Seychelles [Lodoicea maldivica (J. F. Gmel.) Pers.] e a árvore-triste (Nyctanthes arbor-tristis L.). 
Muitas dessas plantas ocorrem nos campos do Mondego, por onde Camóes, provavelmente, passeou quando esteve em Coimbra (1535-1544). Segundo J. H. Saraiva ${ }^{16}$, Camóes foi aio daquela que foi a sua grande paixão (platónica?), Violante de Andrade, casada com Francisco de Noronha e que residiam em S. Martinho do Bispo, povoação da margem esquerda do Mondego, fronteira a Coimbra. Que Violante tivesse constituído uma paixão marcante na vida do poeta, parece presumível pelo teor de alguns do seus poemas, embora ele devesse ter tido o cuidado de evitar citar o nome dela. Também é de referir que na época em que Camóes viveu (século xvi), os poetas referiam, por vezes, flores nos seus poemas amorosos (Natividade, 1970; Ventura, 1928-1936), como, por exemplo, Garcilaso de la Vega (1501-1536), que refere, por exemplo, a rosa e a açucena no soneto "En tanto que de rosa y azucena"; o lírio e a rosa na écloga a Salicio "el blanco lirio y colorada rosa" e até a violeta na ode "a la flor de gnido" (y cómo por ti sola,/ y por tu gran valor y hermosura,/ convertido en vïola,/ llora su desventura/ el miserable amante en tu figura.). Mas, Camóes não só o faz utilizando habilidades, transformando engenhosamente o termo viola em Violante, como refere várias vezes Violante nos seus poemas amorosos.

Há, pelo menos, dois sonetos onde Camóes revela, claramente, o nome da sua apaixonada. Num deles, utiliza os seus referidos malabarismos linguísticos:

Num jardim adornado de verdura,

A que esmaltam por cima várias flores,

Entrou um dia a Deusa dos amores,

Co’a Deusa da caça e da espessura.

Diana tomou logo ũa rosa pura,

Vénus um roxo lírio, dos melhores;

Mas excediam muito às outras flores

As violas na graça e fermosura.

Perguntam a Cupido, que ali estava,

Qual daquelas três flores tomaria,

Por mais suave, pura e fermosa.

Sorrindo-se, o Menino lhe tornava:

-Todas fermosas são; mas eu queria

Viol'antes que lírio, nem que rosa.

16 Cf. J. H. SARAIVA, Vida ignorada de Camões, op. cit., pp. 80-85; 121-136. 
Noutro soneto, escreve claramente o nome dela:

A violeta mais bela que amanhece

No vale, por esmalte da verdura,

Com seu pálido lustre e fermosura,

Por mais bela, Violante, te obedece.

Perguntas-me porquê? Porque aparece

Em ti seu nome e sua cor mais pura;

E estudar em teu rosto só procura

Tudo quanto em beldade mais florece.

Oh luminosa flor, oh Sol mais claro,

Único roubador do meu sentido,

Não permitas que Amor me seja avaro!

Oh penetrante seta de Cupido,

Que queres? Que te peça, por reparo,

Ser, neste vale, Eneias desta Dido?

Note-se que Camóes, neste último verso refere nitidamente o vale do Mondego, quando diz "neste vale".

O nome de Violante também está bem expresso num poema publicado pela primeira vez em 1861 e que Juromenha classificou como Écloga XIV (Nas ribeiras do Tejo, a uma areia...) e que muitas ediçóes modernas de obras de Luís de Camóes (e. g. Costa Pimpão, 2005; Hernâni Cidade, 2005) omitem com o fundamento de descoberta tardia:

No bosque a Violante vi um dia,

Doce princípio destas doces dores;

A flor caía nela e parecia

Dizer caindo: aqui reinam amores!

Humilde em tanta glória, ela se ria

E errando iam sobre ela várias flores.

Eu, que vencido fui dum error cego,

Àquele honesto riso est'alma entrego.”

Aliás, a primeira vez que Camões refere o nome desta sua grande paixão, é num soneto escrito em galego e que talvez seja o mais antigo testemunho das iniciais tentativas literárias do poeta (Saraiva, 1982): 
A lá en Monte Rei, en Bal de Laça

A Biolante bi, beira de um rio,

Tão fermosa en berdá, que quedé frio

De ber alma imortal en mortal maça!

De um alto e lindo copo a seda laça

A pastora sacaba, fio a fio.

Quando the disse: Morro! Corta o fio!

Bolbeu: Não cortarei! Seguro passa!

- E como passarei, se eu acá quedo?

Se passar, respondi, não bou seguro

Que este corpo sem alma morra cedo!

- Com a minha, que lebas, te asseguro

Que não morras, Pastor! - Pastora hei medo,

O quedar me parece mais seguro!

Durante muitas dezenas de anos esta paixão de Camóes permaneceu desconhecida, pois a partir do primeiro biógrafo (Pedro de Mariz, vinculado à família Noronha) ela foi não só convenientemente ignorada (Mariz omitiu os primeiros 25 anos de vida de Camóes) devido à posição social do casal Noronha, como também houve biógrafos que inventaram amores inexistentes, de modo a desacreditar-se esta verdadeira paixáo do poeta, como foi o caso de Diogo Paiva de Andrade, que pretendeu mostrar que a amante de Camóes não fora a sua tia Violante, mas uma Catarina de Ataíde.

Por se terem escrito muitas falsidades sobre a vida do poeta, actualmente não só se sabe muito pouco sobre factos reais, como também o que se pode elaborar são meras conjecturas conseguidas de interpretações retiradas da sua obra poética (Épica e Lírica), teatro e cartas.

Efectivamente, os tempos de Coimbra e essa paixão por Violante, parecem ter marcado profundamente a vida do poeta. A tal ponto, que em vários poemas ele refere saudosamente o Mondego e até n'Os Lusíadas, como no episódio de Inês de Castro (Canto III, 120):

Estavas, linda Inês, posta em sossego,

De teus anos colhendo o doce fruto,

Naquele engano da alma, ledo e cego,

Que a Fortuna não deixa durar muito;

Nos saudosos campos do Mondego,

De teus fermosos olhos nunca enxuto,

Aos montes ensinando e às ervinhas

O nome que no peito escrito tinhas. 
Claro que era ele que tinha saudades dos campos do Mondego (estava na Ásia, quando escreveu Os Lusiadas) e não Inês de Castro, assassinada em 1355 (7 de Janeiro). Reparar, também, que ele refere as "ervinhas" dos campos do Mondego, que ele cita em muitos poemas da Lírica, pois devia conhecê-las dos campos do Mondego, como, por exemplo as boninas (Bellis sp.) e as rosas das roseiras bravas (Rosa sp.) na Redondilha "A uma mulher que se chamava Grácia de Morais":

\footnotetext{
Vêem-se rosas e boninas,

Olhos, nesse vosso ver;

Vêem-se mil armas arder

No fogo dessas meninas.
}

E que também refere no episódio de Inês de Castro (Canto III, 134):

Assi como a bonina, que cortada

Antes do tempo, foi cândida e bela,

Sendo das mãos lascivas mal tratada

Da menina que a trouxe na capela,

O cheiro traz perdido e a cor murchada:

Tal está morta, a pálida donzela,

Secas do rosto as rosas, e perdida

A branca e viva cor co'a doce vida.

Há, pelo menos, duas espécies de boninas (actualmente designamo-las por margaridas), Bellis perennis L. e Bellis sylvestris Cirillo e duas de roseiras, Rosa canina L. e Rosa sempervirens L., nos campos que marginam o Mondego em S. Martinho do Bispo, onde residia Violante.

Há várias alusôes na Lírica a essa época apaixonante que o poeta viveu nos campos do Mondego, como, por exemplo, na canção da autobiografia poética:

Vão as serenas águas

Do Mondego descendo,

Mansamente, que até ao mar não param;

Por onde minhas mágoas,

Pouco a pouco crescendo,

Pera nunca acabar se começaram. 
Nesta florida terra

Leda, fresca e serena,

Ledo e contente para mim vivia,

Em paz, com minha guerra,

Contente com a pena

Que de tão belos olhos procedia...

Assim como no soneto em que refere o rio e a bela amada:

Doces águas e claras do Mondego,

Doce repouso de minha lembrança,

Onde a comprida e pérfida esperança

Longo tempo após si me trouxe cego;

De vós me aparto; mas, porém, náo nego

Que inda a memória longa, que me alcança,

Me não deixa de vós fazer mudança,

Mas quanto mais me alongo, mais me achego.

Bem pudera Fortuna este instrumento

D’alma levar por terra nova e estranha,

Oferecido ao mar remoto e vento;

Mas alma, que de cá vos acompanha,

Nas asas do ligeiro pensamento,

Para vós, águas, voa, e em vós se banha.

Outras flores de plantas que vegetam nos campos do Mondego, são frequentemente referidas por Camões nos seus poemas, como, por exemplo, lírios (Iris sp.), cravos (Dianthus sp.), jasmim (Jasminum sp.), jacintos [Hyacynthoides hispanica (Mill.) Rothm.], andorinhas (Chelidonium majus L.), abrolhos (Tribulus terrestres L.) e violetas (Viola sp.).

Eis alguns exemplos na Lírica:

Sonetos (um dos dedicados a Violante)

Num jardim adornado de verdura,

A que esmaltam por cima várias flores,

Entrou um dia a Deusa dos amores,

Co’a Deusa da caça e da espessura.

Diana tomou logo ũa rosa pura, 
Vénus um roxo lírio, dos melhores;

Mas excediam muito às outras flores

As violas na graça e fermosura.

Perguntam a Cupido, que ali estava,

Qual daquelas três flores tomaria,

Por mais suave, pura e mais fermosa.

Sorrindo-se, o Menino lhe tornava:

-Todas fermosas são; mas eu queria

Viol'antes que lírio, nem que rosa.

\section{Éclogas (D. António de Noronha)}

Porque escondes a luz do Sol à gente,

Que nesses olhos trazes, bela e pura?

Mais bela, mais suave e mais fermosa,

Que o lírio, o jasmim, o cravo e a rosa?

\section{Éclogas (Duriano)}

Por ti, a noite escura me contenta;

Por ti, o claro dia me aborrece;

Abrolhos pera mim são frescas flores;

A doce filomela me entristece;

Todo contentamento me atormenta

Co'a contemplação de teus amores;

As festas dos pastores,

Que podem alegrar toda a tristeza.

\section{Odes}

Já a calma nos deixou

Sem flores as ribeiras graciosas;

Já de todo secou

Os cravos, lírios e as purpúreas rosas;

Fogem da calma grave os passarinhos

Pera o sombrio amparo de seus ninhos. 
O campo não o esmaltam

Flores, mas só abrolhos

$\mathrm{O}$ fazem feio; e cuido que lhe faltam

Ouvidos pera mim, pera vós olhos.

Mas faça o que quizer o vil costume;

Que o Sol, que em vós está,

$\mathrm{Na}$ escuridão dará mais claro lume.

\section{Elegias}

Se não tem as delícias de Corinto,

E se de Pário os mármores lhe faltam,

O piropo, a esmeralda e o jacinto;

Se suas casas de ouro não se esmaltam,

Esmalta-se-lhe o campo de mil flores,

Onde os cabritos seus, comendo, saltam.

\section{Redondilhas (carta a uma dama)}

Se alguém os olhos quiser

Às andorinhas quebrar,

Logo a mãe, sem se deter,

Ũa erva lhe vai buscar

Que lhe faz outros nascer.

Redondilhas (votas a mote alheio)

As flores me torna abrolhos,

A morte me determina

Quem eu trouxe de menina

Nas meninas dos meus olhos.

\section{Redondilhas (votas a mote)}

Vi terra florida

De lindos abrolhos

Lindos pera os olhos, 
Duros pera a vida;

Mas a rês perdida

Que tal erva pasce

Em forte hora nasce.

Que a flora dos campos do Mondego fazia parte da observação quotidiana do poeta, é também testemunhada pela referência nos seus poemas de árvores da floresta ripícola das margens do rio, como, por exemplo, salgueiros (Salix sp.), freixos (Fraxinus angustifolia Vahl), ulmeiros (Ulmus minor Mill.) e choupos ou álamos (Populus sp.), assim como as silvas (Rubus sp.) que orlam os nossos campos e florestas.

Redondilhas (Babel e Sião)

Assim, depois que assentei

Que tudo o tempo gastava,

Da tristeza que tomei,

Nos salgueiros pendurei

Os órgãos com que cantava.

Éclogas (Frondélio)

Aquele dia, as águas não gostaram

As mimosas ovelhas, e os cordeiros

O campo encheram de amorosos gritos.

Não se dependuraram dos salgueiros

As cabras, de tristeza, mas negaram

$\mathrm{O}$ pasto a si, e o leite aos cabreiros.

\section{Éclogas (Agrário)}

Estava o triste amante recostado,

Chorando ao pé de um freixo o triste caso

Que o falso amor lhe tinha destinado. 


\section{Éclogas (dos Faustos)}

Entre as ervas dos prados

Não há machos e fêmeas conhecidas,

E junto ũa da outra permanece?

Não estão carregados

Os ulmeiros das vides retorcidas,

Onde o cacho enforcado amadurece?

Destarte vão as Ninfas, que, deixando

De seu despojo os ramos carregados,

Nuas por entre as silvas vão voando.

Éclogas (Ao duque de Aveiro)

Embebido num longo esquecimento

De si e do seu gado e pobre fato,

Após um doce sonho e fingimento,

Rompendo as silvas hórridas do mato,

Vai por cima de outeiros e penedos,

Fugindo, enfim, de todo humano trato.

\section{Éclogas (Umbrano)}

Toca Frodélio, toca a doce lira;

Que, daquele verde álamo sombrio,

A branda filomela, entristecida,

Ao saudoso canto te convida.

\section{Éclogas (Agrário)}

Seus furiosos touros coroava,

E nos álamos altos escrevia

Teu nome, Enone, quando a ti só amava. 


\section{Odes}
Meneia os altos freixos
A branda viração, de quando em quando,
E, de entre os vários seixos,
O líquido cristal sai murmurando;
As gotas, que das alvas pedras saltam,
O prado, como pérolas, esmaltam.

Como também cita árvores características dos carvalhais, de que ainda existem resquícios em S. Martinho do Bispo, como carvalhos (Quercus sp.), castanheiros (Castanea sativa Mill.) e faia (Fagus sylvatica L.), alguns arbustos, como a murta ou mirto (Myrtus cummunis L.), a aveleira (Corylus avellana L.), o zambujeiro [Olea europaea L. var. sylvestris (Mill) Lehr] e as, já referidas, silvas (Rubus sp.):

Éclogas (Ao duque de Aveiro)

Que razão há, pastor, porque te saias

Pero nosso escamoso e vil terreno

Dos mil floridos mirtos e altas faias?

Fermosa Dinamene, se dos ninhos

Os implumes penhores já furtei

À doce filomela, e dos murtinhos

Pera ti, fera! As flores apanhei;

E quaisquer o seu vate coroaram

De capelas idónes e fermosas,

Que as Ninfas lhe teceram e ordenaram:

A Agrário, de murtinhos e de rosas;

Éclogas (À morte D. António de Noronha) (Frondélio)

Que vejo este carvalho, que queimado

Tão gravemente foi do raio ardente,

Não seja ora prodígio que declare

Que o bárbaro cultor meus campos are. 


\section{(Umbrano)}

Enquanto do seguro azambujeiro

Nos pastores de Luso houver cajados,

E o valor antigo, que primeiro

Os fez no mundo tão assinalados,

Não temas tu, Frondélio companheiro,

Que em nenhum tempo sejam subjugados,

Nem que a cerviz indómita obedeça

A outro jugo algum que se ofereça.

\section{Éclogas (dos Faustos)}

Porém a espessa mata, mensageira

Da futura cilada, co'o rugido

Dos raminhos dũa áspera aveleira,

Mostrando a um dos Deuses escondido,

Todas tamanha grita alevantaram,

Como se fosse o monte destruído.

\section{Sonetos}

A fermosura desta fresca serra

E a sombra dos verdes castanheiros,

O manso caminhar destes ribeiros,

Donde toda a tristeza se desterra;

O rouco som do mar, a estranha terra,

O esconder do sol pelos outeiros,

O recolher dos gados derradeiros,

Das nuvens pelo ar a branda guerra;

Assim como flores ornamentais já vulgarizadas na época, como a açucena ou cecém (Lilium candiduma L.) e rosas (Rosa sp,): 


\title{
Sonetos
}

\author{
Tornai essa brancura à alva açucena, \\ E essa purpúrea cor às puras rosas; \\ Tornai ao Sol as chamas luminosas \\ Dessa vista que a roubos vos condena. \\ Tornai à suavíssima Sirena \\ Dessa voz as cadências deleitosas; \\ Tornai a graça às Graças, que queixosas \\ Estão de a ter por vós menos serena;
}

$\mathrm{Na}$ Lírica refere ainda algumas (muito poucas) plantas utilizadas na alimentação como repolhos (Brassica oleracea L. var. capitata L.), alhos (Allium sativum L.), alface (Lactuca sativa L.) e condimentares como a manjerona (Origanum majorana L.) e hortelá (Mentha arvenses L.).

Redondilhas (a quarta, a João Lopes Leitão)

Tendes nem migalha assada,

Cousa nenhũa de molho,

E nada feito em empada,

E vento de tigelada,

Picar no dente em repolho,

De fumo tendes tassalhos;

Ave de pena que sente

Quem da fome anda doente;

Bocejar de vinho e de alhos,

Manjar em branco excelente.

Odes

Pelo moço escolhido,

Onde mais se mostravam as três Graças;

Que Vénus escondido

Pera si teve um tempo entre as alfaças,

Pagou co'a morte fria

A má vida que a muitos já daria. 


\section{Éclogas (dos Faustos)}

Ali se vêem os mirtos circunstantes

Que a cristalina Vénus encobriram

Da companhia dos Faustos petulantes;

Hortelá, manjerona ali respiram

Onde nem frio Inverno ou quente Estio

As murcharam jamais, ou secas viram.

Finalmente, Camóes refere na Lírica (Redondilhas) uma planta asiática e aromática, igualmente alusiva ao amor, mas que não encontramos referida n'Os Lusíadas, que é a árvore-triste (Nyctanthes arbor-tristis L.), cujas flores (brancas e aromáticas) só abrem à noite. Sendo uma planta aromática, os asiáticos usam-na em fitoterapia e aromatizam a comida com as flores. Por as flores abrirem apenas de noite, nalgumas regióes asiáticas tem algum significado mitológico, mas Camóes, na Lírica refere-a com o habitual sentimento amoroso.

(Carta a uma dama)

Ũa árvore se conhece

Que, na geral alegria,

Ela tanto se entristece

Que, como é noite, floresce,

E perde as flores de dia.

Escrevem vários autores

Que, junto da clara fonte

Do Ganges, os moradores

Vivem do cheiro das flores

Que nascem naquele monte.

(Glosa a mote alheio)

Por isso vós, arvoredos,

Que já nos meus olhos vistes

Mais alegrias que medos,

Se mos quereis fazer ledos,

Tornai-vos agora tristes. 


\title{
A ILHA DOS AMORES
}

É interessante que o poeta refere as plantas e flores dos campos do Mondego no episódio da Ilha dos Amores (Insula Divina) d'Os Lusíadas, quando, nesta obra ele normalmente refere, quase exclusivamente, plantas asiáticas. Alguns biógrafos tentaram localizar esta Ilha dos Amores, algures num dos arquipélagos do Oceano Índico ${ }^{17}$ e até na ilha de Santa Helena ${ }^{18}$. Ora isso não pode ser, pois ele cita plantas europeias e particularmente aquelas que lhe lembravam os campos do Mondego, onde viveu a sua grande paixão. Senão vejamos:

\section{Canto IX}

\author{
As árvores agrestes, que os outeiros \\ Têm com frondente coma enobrecidos, \\ Álamos são de Alcides, e os loureiros \\ Do louro Deus amados e queridos; \\ Mirtos de Citereia, co'os pinheiros \\ De Cibele, por outro amor vencidos; \\ Está apontando o agudo cipariso \\ Para onde é posto o etéreo Paraíso.
}

Nesta estância 57, cita os álamos (choupos) [Populus sp.; talvez o choupo-negro Populus nigra L., o mais comum nas margens do rio e não o choupo-branco (Populus alba L.), menos presente no campo], os loureiros (Laurus nobilis L.), os mirtos (murtas) (Myrtus communis L.), que são comuns, ainda hoje, nos campos do Mondego; o cipariso (cipreste) (Cupressus sempervirens L.) e o pinheiro de Cíbele (pinheiro de Alepo) (Pinus halepensis Mill.), árvores introduzidas talvez pelos romanos e comuns (ainda hoje) nos cemitérios e casas senhoriais da região. Uma das razóes que levaram Joáo Vidago a identificar a Ilha dos Amores com a Ilha de Santa Helena foi "em especial, a enumeração das espécies vegetais, flores e frutos, que nela abundavam". Realmente, as naus faziam escala na Ilha de Santa Helena para se abastecerem de água, frutas e vegetais que os portugueses ali haviam introduzido e cultivavam. Mas isso não é razão suficiente para se considerar que terá sido nesta ilha que o poeta baseara a Ilha dos Amores, pois ele refere plantas

17 Itha de Moçambique (Pedro de Marız, "Ao estudioso da lição poética" — Pedro Craesbeek, Os Lusíadas, comentados por Manoel Correa. Lisboa, 1613); Ilha do Ceilão (Manuel de Faria e SouSA, Lusíadas de Luís de Camões. Madrid; 1639); Itha de Bombaim (Luiz da Cunha GonçaLves, Estudos Camonianos. Porto, 1947).

18 João VIDAGo, "Ilha de Santa Helena, Ilha dos Amores, Escala da "Carreira da Índia" (1502-1625)", Boletim da Sociedade de Geografia de Lisboa, Série 94ª, n.os 7-,10-12 (1976), pp. 153-175. 
e árvores europeias (álamos, loureiros, pinheiros, o cipreste, o cecém, as boninas, etc.) que não existiam, nem eram cultivadas, na Ilha de Santa Helena.

Nas estâncias 61 e 62 deste episódio (Ilha dos Amores) refere as flores [violas (violetas) (Viola sp; talvez a Viola riviniana Rchb., comum nos campos do Mondego ou o cultivado amor-perfeito, Viola tricolor L.), lírio roxo (Iris sp.; talvez o híbrido cultivado desde os tempos romanos, Iris $x$ germanica L. ou o espontâneo na região, Iris subbiflora Brot.), rosa (Rosa sp.), cecém (açucena) (Lilium candidum L.), manjerona (Origanum majorana L.), hiacintinas ${ }^{19}$ (jacintos) (provavelmente o jacinto cultivado, Hyacinthus orientalis L.; ou jacinto-dos-campos, Hyacinthoides hispanica (Mill.) Rothm.), boninas (margaridas) (Bellis sp., ocorrendo duas espécies nos campos do Mondego, Bellis sylvestris Cirillo e Bellis perennis L.], que também refere, como vimos, nos poemas líricos "amorosos" e que são flores de plantas comuns nos prados mondeguinos. Também cita o pomo, talvez referindo-se ao fruto da "perdição" de Adão, a maçã.

Para julgar, difícil cousa fora,

No Céu vendo e na terra as mesmas cores,

Se dava às flores cor a bela Aurora,

Ou se lhe dão a ela as belas flores.

Pintando estava ali Zéfiro e Flora

As violas da cor dos amadores ${ }^{20}$,

O lírio roxo, a fresca rosa bela,

Qual reluze nas faces da donzela;

A cândida cecém, das matutinas

Lágrimas rociada, e a manjerona;

Vêem-se as letras nas flores hiacintinas,

Táo queridas do filho de Latona;

Bem se enxerga nos pomos e boninas

Que competia Clóris com Pomona.

Pois, se as aves no ar cantando voam,

Alegres animais o chão povoam.

19 Augusta Faria Gersão Ventura (1928), pelo facto de Camões referir que se vêem letras nas flores hiacintinas, considera tratar-se de Delphinium ajacis L., cujo nome válido é Consolida ajacis (L.) Schur. (esporas-bravas ou ciúmes), planta de flores azuis, mas muito distinta das plantas de flores azuis vulgarmente conhecidas por jacintos e que é relativamente comum nos campos do Mondego.

20 Augusta Faria Gersão Ventura (1932) considera tratar-se de Matthiola incana (L.) R. Br. (goiveiro-encarnado), uma planta comum nos jardins. 
$\mathrm{Na}$ estância 58 são os frutos comuns, na altura, na região; as cerejas (Prunus avium (L.), as amoras (Morus nigra L.) e o pomo da Pérsia [pêssego; Prunus persica (L.) Batsch]:

Os dons que dá Pomona, ali Natura

Produze, diferente nos sabores,

Sem ser necessidade de cultura,

Que sem ela se dáo muito melhores:

As cerejas purpúreas na pintura,

As moras, que o nome têm de amores,

O pomo que da pátria Pérsia veio,

Melhor tornado no terreno alheio;

Na estância 59 volta a citar frutos dessa altura [romãs (Punica granatum L.), pêras (Pyrus communis L.) e uvas (Vitis vinifera L.] e as vinhas de enforcado (as videiras são orientadas para treparem pelas árvores acima, afastando a ramada da geada do solo, podendo, assim dar uvas em cachos que ficam pendurados nos ramos das árvores, lembrando enforcados), que, actualmente, só se observam no Norte do país, mas que nessa altura devia ser a maneira usual de cultivarem a vinha. Aqui, o poeta diz que a vinha trepa pelos ulmeiros (árvores comuns nas margens do Mondego) (Ulmus minor Mill.), no Norte usam como árvores de suporte das vides, castanheiros, carvalhos, plátanos e até oliveiras (no Norte as oliveiras têm de ter porte arbóreo para a ramada estar longe da geada do solo e, assim, darem azeitona).

\footnotetext{
Abra a romã, mostrando a rubicunda

Cor, com que tu, rubi, teu preço perdes;

Entre os braços do ulmeiro está a jucunda

Vide, c'uns cachos roxos e outros verdes;

E vós, se na vossa árvore fecunda,

Peras piramidais, viver quiserdes,

Entregai-vos ao dano que co'os bicos

Em vós fazem os pássaros inicos.
}

O poeta refere também os narcisos neste episódio (estância 60), pois, de facto, existem muitas espécies de narcisos (Narcissus sp.) em Portugal, nomeadamente, nos campos do Baixo Mondego. É interessante notar que o poeta refere o pormenor de as flores destas plantas serem nutantes (“a cabeça a flor Cyfisia inclina”), como, na realidade, são na grande maioria das espécies de narcisos. 
Pois a tapeçaria bela e fina,

Com que se cobre o rústico terreno,

Faz ser a de Aqueménia menos dina;

Mas o sombrio vale mais ameno.

Ali a cabeça a flor cifísia inclina,

Sôbolo tanque lucido e sereno;

Florece o filho e neto de Ciniras,

Por quem tú, Deusa páfia, inda suspiras.

Das plantas mais interessantes referidas por Camóes na Ilha dos Amores, são os citrinos, que são plantas aromáticas de origem asiática (portanto, o normal n’Os Lusiadas) e já muito cultivados nessa altura na Europa Ocidental. Cita a laranjeira [Citrus sinensis (L.) Osbeck], a cidreira (Citrus medica L.) e o limão [Citrus limon (L.) Burm. f.]. Mas, como estamos na Ilha dos Amores, a referência "amorosa" tem de estar presente, quando diz que "A laranjeira tem no fruito lindo a cor que tinha Dafne nos cabelos;" e "Os fermosos limões ali, cheirando, estão virgíneas tetas imitando.” (estância 56).

Mil árvores estão ao céu subindo,

Com pomos odoríferos e belos:

A laranjeira tem no fruito lindo

A cor que tinha Dafne nos cabelos;

Encosta-se no chão, que está caindo

A cidreira co'os pesos amarelos;

Os fermosos limões ali, cheirando,

Estão virgíneas tetas imitando.

Da mesma maneira, com alusão "amorosa”, também cita o limão na Lírica, nas Redondilhas (Voltas a mote e alheio):

Verdes são os campos,

De cor de limáo;

Assim são os olhos

Do meu coração. 


\section{LISTA DAS PLANTAS D’OS LUSÍADAS}

As plantas indubitavelmente identificadas estão a negrito. Os casos que indicam apenas o nome do género, sem o restritivo específico (ex.: Rosa sp.), correspondem a casos em que não é possível identificar a espécie, como, por exemplo, no caso de Rosa sp., indica-se que ou se trata de rosas de roseiras cultivadas, normalmente cultivares resultantes de cruzamentos entre espécies diferentes (híbridos) e manipulação genética ou de roseiras silvestres e, neste caso, era preciso saber onde estava Camóes quando escreveu o poema (por exemplo, se estivesse nos campos do Mondego seria a Rosa sempervirens L. ou a Rosa canina L.). Os outros nomes correspondem a identificaçóes incorrectas encontradas na literatura camoniana, ou determinaçóes de exactidão impossível, ou a sinónimos de nomes a negrito. Para cada espécie indica-se um Canto e respectiva estância onde a planta é referida. Os nomes vulgares entre aspas, correspondem a nomes referidos por Camóes e, actualmente, em desuso ou nomes escritos, por conveniência elucidativa, em língua estrangeira.

Adonis annua L.

Adonis autumnalis L.

Aloe forbesii Bak.f.

Aloe perryi Bak.

Aloe succotrina Lam.

Aloe vera (L.) Burm.f.

Antiaris toxicaria (Rumph. ex. Pers.) Lesch.

Aquilaria malaccensis Lam.

Balsamodendrumn myrrha T. Nees

Bellis sp.

Bellis perennis $\mathrm{L}$.

Bellis sylvestris Cirillo

Borassus aethiopium Mart.

Borassus flabellifer L.

Boswellia sacra Flueck.

Caesalpinia echinata Lam.

Caesalpinia peltophoroides Benth.

Caryophyllus aromaticus L.

Cerasus avium (L.) Moench

Cinnamomum aromaticum Nees

Cinnamomum verum J. Presl

Cinnamomum zeylanicum Sin.

Citrus aurantium L.

Citrus limon (L.) Burm.f.

Citrus limomum Sin.

Citrus medica L.
Lágrimas-de-sangue; Olhos-de-perdiz; Casadinhos IX; 60

Lágrimas-de-sangue; Olhos-de-perdiz; Casadinhos IX; 60

Aloé de Socotra $\quad X ; 137$

Aloé de Socotra $\quad x_{;} 137$

Aloé $\quad X_{;} ; 137$

Aloé; Aloé-babosa; Erva-babosa; Erva-azebra $\quad X_{;} ; 137$

Árvore-de-upas; upas-antiar (veneno) $\quad X_{i} 44$

Pau-de-águia; "Aloé" (Biblia) X; 129

Mirra $\quad X ; 135$

Margaridas; "Boninas" IX; 62

Margaridas; "Boninas" IX; 62

Margaridas; "Boninas" IX; 62

Palmeira-leque; "Mevuma" (vandau) I; 46

Palmeira de Palmira $\quad$ I; 46

Incenso; Incenseiro; Olíbano; Árvore-do-incenso $\quad$ X; 101

Pau-brasil $x ; 140$

Pau-brasil $\quad x ; 140$

Cravinho; Cravinho da índia $\quad X ; 132$

Cerejeira; Cerdeira; cereja (fruto) IX; 58

Caneleira da China; Cássia da China $\quad$ X; 51

Caneleira do Ceilão; Caneleira da Índia $\quad$ X; 51

Caneleira do Ceilão; Caneleira da Índia $\quad$ X; 51

Laranjeira-amarga; laranja-amarga (fruto) IX; 56

Limoeiro; limão (fruto) IX; 56

Limoeiro; limão (fruto) IX; 56

Cidreira; cidra (fruto); cidrão (fruto) IX; 56 
Citrus sinensis (L.) Osbeck

Commiphora abyssinica Sin.

Commiphora myrrha (Nees) Engl.

Cupressus sempervirens $\mathrm{L}$.

Dryobalanops aromatica Gaërtn.

Dryobalanops sumatrensis (Gmel.) Kost.

Fagus sylvatica L.

Gladiolus illyricus W.D.J. Koch

Gladiolus italicus Mill.

Gladiolus segetum Ker-Gawl.

Gnaphalium sanguineum L.

Gossypium herbaceum L.

Hedera helix L.

Helichrysum sanguineum (L.) Kostel.

Hyacinthoides hispanica (Mill.) Rothm.

Hyacinthus sp.

Hyacinthus orientalis L.

Hyphaena obovata Furtado

Indigofera tinctoria L.

Iris sp.

Iris subbiflora Brot.

Jasminum sp.

Jasminum fruricans L.

Laurus nobilis L.

Lilium candidum $\mathrm{L}$.

Lodoicea maldivica (J.F. Gmel.) Pers.

Lodoicea sechellarum Labill.

Malus sylvestis (L.) Mill.

Matthiola incana (L.) R.Br.

Morus nigra $\mathrm{L}$.

Myristica fragans Houtt.

Myrtus communis L.

Narcissus sp.

Narcissus poeticus L.

Narcissus tazetta L.

Olea europaea L. var. europaea

Origanum majorana $\mathrm{L}$.

Persica vulgaris Mill.

Phoenix dactylifera L.

Phoenix reclinata Jacq.

Pinus halepensis Mill.

Pinus pinea $\mathrm{L}$.
Laranjeira-doce; laranja-doce (fruto)

IX; 56

Mirra

X; 135

Mirra

$x ; 135$

Cipreste; "Cipariso"

IX;57

Canforeira de Bornéu; Canforeira da Malásia

X; 133

Canforeira de Bornéu; Canforeira da Malásia

$x ; 133$

Faia

X; 34

Espadana-dos-montes-de-folhas-largas

$\mathrm{IX} ; 62$

Espadana-das-searas

IX; 62

Espadana-das-searas

IX; 62

Sangue-dos-macabeus

III; 97

Algodoeiro-asiático; algodão (pêlo da semente)

V; 76

Hera

II; 36

Sangue-dos-macabeus

III; 97

Jacinto; "hiacintina"

IX; 61

Jacinto; "hiacintina"

IX; 61

Jacinto; "hiacintina"

IX; 61

"Matcheu" (vandau)

I; 46

Anilerira; Índigo

V; 76

Lírio

II; 37

Lírio-roxo

IX; 61

Jasmineiro; jasmim (flor)

$x ; 1$

Jasmineiro-do-campo; jasmim (flor)

X; 1

Loureiro, Louro

IX; 57

Açucena; "Cecém" ; "Susen" (árabe)

$I X ; 62$

Palmeira das Seicheles; coco-do-mar (fruto)

X; 136

Palmeira das Seicheles; coco-do-mar (fruto)

X; 136

Macieira-brava; maçã (fruto);"maçã-de-ouro"

IV; 55

Goiveiro-encarnado

$I X ; 61$

Amoreira-negra; "Mora"; amora (infrutescência)

IX; 58

Moscadeira; noz-moscada (semente arilada)

X; 133

Murta; Murteira; "Mirto"

IX; 57

Narciso; "Flor cifísia"

IX; 60

Narciso-dos-poetas

$I X ; 60$

$\mathrm{IX} ; 60$

VI; 13

$\mathrm{IX} ; 62$

IX; 58

X; 42

I; 46

IX; 57

IX; 57 
Piper betle L.

Piper nigrum L.

Piper officinarum $\mathrm{L}$.

Piper retrofractum $\mathrm{L}$.

Populus sp.

Populus alba L.

Populus alba L.

Populus nigra $L$.

Prunus avium L.

Prunus persica (L.) Batsch

Punica granatum L.

Pyrus communis L.

Quercus sp.

Quercus robur L.

Rosa sp.

Rosa x centifolia L.

Santalum album L.

Strophanthus kombe Oliv.

Strophanthus petersianus Klotsch

Strychnos nux-vomica $\mathrm{L}$.

Strychnos tieute Lesch.

Strychnos toxifera R.H. Schomb. ex Benth.

Styrax benzoin Dryand.

Syzygium aromaticum (L.) Merr. \& Perry

Triticum sp.

Triticum aestivum L.

Triticum vulgare Vill.

Uhnus campestris auct., non L.

Ulmus minor Mill.

Viola sp.

Viola odorata L.

Viola riviniana $\mathrm{Rchb}$.

Vitis vinifera $\mathrm{L}$.
Bétele

VII; 58

Pimenteira; pimenta-negra (semente) IX; 14

Pimenteira; pimenta-longa de Java (semente) X; 123

Pimenteira; pimenta-longa de Java (semente) X; 123

Choupo; Álamo; "Álemo"

IX; 57

"Faia"

X; 34

Choupo-branco; Álamo-branco; "Álemo"

IX; 57

Choupo-negro; Álamo-negro; “Álemo"

IX; 57

Cerejeira; Cerdeira; cereja (fruto)

IX; 58

Pessegueiro; pêssego (fruto); "pomo" (fruto)

IX; 58

Romãzeira; Romeira; romã (fruto)

IX; 59

Pereira; pêra (fruto)

IX; 59

Carvalho; bolota (fruto)

X; 34

Carvalho-comum; bolota (fruto)

$x ; 34$

Roseira; rosa (flor)

IX; 61

Roseira-pálida; rosa-pálida (flor)

IX; 61

Sândalo-branco; Pau-sândalo

X; 134

Estrofanto;"kombi" (veneno)

I; 86

Estrofanto;"kombi" (veneno)

I; 86

Árvore-da-noz-vómica; noz-vómica (fruto)

X; 44

"Upas tieuté" (veneno)

X; 44

$x ; 44$

X; 135

Benjoim

X; 132

X; 27

Trigo

IX; 27

Trigo; Trigo-mole

$1 X ; 27$

Trigo

IX; 27

Ulmeiro; Negrilho

IX; 59

Ulmeiro; Negrilho

IX; 59

Violeta; "Viola"

IX; 61

Violeta; Amor-perfeito; "Viola"

IX; 61

Violeta; "Viola"

IX; 61

Videira; "Vide"

IX; 59 


\section{LISTA DAS PLANTAS DA LÍRICA}

Os casos que indicam apenas o nome do género, sem o restritivo específico, como, por exemplo Salix sp., correspondem a casos em que não é possível identificar a espécie, pois, neste caso (Salix sp.), era preciso saber onde estava Camóes quando escreveu o poema. Os nomes vulgares entre aspas correspondem a nomes referidos por Camóes e, actualmente, em desuso ou nomes escritos, por conveniência elucidativa, em língua estrangeira. Para cada espécie indicase a composição poética lírica onde a planta é referida. Notar que as rosas são as únicas flores referidas em todas as formas líricas de composição poética.

Allium sativum $\mathrm{L}$.

Bellis sp.

Brassica oleracea L. var. capitata L. Castanea sativa L.

Chelidonium majus L.

Citrus limon (L.) Burm. f.

Corylus avellana $\mathrm{L}$.

Dianthus caryophyllus L.

Fagus sylvatica $\mathrm{L}$.

Ficus carica L.

Fraxinus angustifolia Vahl

Hedera helix L.

Hyacinthus sp.

Iris sp.

Jasminum sp.

Lactuca sativa L.

Laurus nobilis $\mathrm{L}$.

Lilium candidum $\mathrm{L}$.

Lodoicea maldivica (J. F. Gmel.) Pers.

Malus sylvestris (L.) Mill.

Mentha sp.

Myrtus communis L.

Nyctanthes arbor-tristis $L$.

Olea europaea L. var. sylvestris (Mill.) Lehr

Origanum majorana L.

Pinus halepensis Mill.

Populus sp.

Quercus sp.

Rosa sp.

Rubussp.

Salix sp.

Tribulus terrestris $\mathrm{L}$.

Ulmus minor Mill.

Viola sp.

Vitis vinifera $\mathrm{L}$.
Alho

Margaridas; "Boninas"

Repolho

Castanheiro; castanha (fruto)

Erva andorinha; "Andorinha"

Limoeiro; limão (fruto)

Aveleira; avelã (fruto)

Craveiro; cravo (flor)

Faia

Figueira; figo (infrutescência)

Freixo

Hera

Jacinto; "Hiacintinas"

Lírio

Jasmim

Alface; "Alfaça"

Loureiro, Louro

Açucena; "Cecém"

Coco-do-mar; "Pomo"

Macieira-brava; macã (fruto); "pomo"

Hortelã

Murta; Murteira; "Mirto"

Árvore-triste

Zambujeiro; "Azambujeiro"

Manjerona

Pinheiro de Alepo

Choupo; Álamo; "Álemo"

Carvalho; bolota (fruto)

Roseira; rosa (flor)

Silva; Amora-da-silva (fruto); "moras"

Salgueiro

Abrolhos

Ulmeiro

Violeta; "viola"

Videira
Redondilhas

Red; Son; Écl; Odes

Redondilhas

Sonetos

Redondilhas

Redondilhas

Éclogas

Éclogas; Odes

Éclogas

Redondilhas

Éclogas; Odes

Éclogas

Elegias

Son; Écl; Odes

Redondilhas; Éclogas

Odes

Sonetos; Odes

Sonetos

Red; Son; Odes

Éclogas

Éclogas

Éclogas; Odes

Redondilhas

Éclogas

Éclogas

Sonetos; Éclogas

Éclogas

Éclogas

Red; Son; Écl; Od; El; Can

Éclogas

Redondilas; Éclogas

Red; Écl; Odes

Éclogas

Sonetos

Éclogas 


\section{BIBLIOGRAFIA FUNDAMENTAL}

Barbosa, Duarte, Livro de Duarte Barbosa. Lisboa, Academia Real das Sciencias, 1813.

Camốes, Luís de, Os Lusíadas. Fac-símile da edição de: Lisboa, Antonio Gốçaluez Impressor, 1572. Edição Fac-símile comemorativa dos 500 anos da Biblioteca da Universidade de Coimbra. [Lisboa], A Bela e o Monstro, 2013.

Cidade, H., "Luís de Camões e suas Afinidades com Garcia de Orta", Garcia de Orta, N. ${ }^{\circ}$ Especial (1972), pp. 155-163.

Cidade, H., Obras completas de Luis de Camôes. 1, Os Lusíadas. Mem Martins, Círculo de Leitores, 1980.

Cidade, H., Obras completas de Luís de Camóes. 2, Teatro e Cartas. Mem Martins, Círculo de Leitores, 1980.

Cidade, H., Obras completas de Luís de Camóes. 3, Lírica. Mem Martins, Círculo de Leitores, 1980.

Cunha, A. Proença da; Silva, A. P. da; Roque, O. R., Plantas e produtos vegetais em fitoterapia. Lisboa, Fundação Calouste Gulbenkian, 2003.

Pimpão, A. J. Costa, Luís de Camôes. Rimas. Coimbra, Almedina, ${ }^{5} 2005$.

Fauvel, A.-A., "Le Cocotier de mer des Iles Seychelles (Lodoicea Sechellarum)", Annales du Musée Colonial de Marseille, Sér. 3, 1 (1915), pp. 169-307.

Ferrão, J. E. M., A Aventura das Plantas e os Descobrimentos Portugueses. 3.a ed. Lisboa, Instituto de Investigação Científica Tropical; Fundação Berardo; Chaves Ferreira- Publicaçôes, S.A., 2005.

Ficalho, Conde de, Flora dos Lusiadas. Lisboa, Academia Real das Sciencias, 1880.

Labillardière, Jean-Jacques H., "Sur le Cocotier de Mer des Maldives", Annales du Muséum National d'Histoire Naturelle 9 (1807), pp. 140-145.

Lionnet, G., The Romance of a palm. Coco de Mer. Bell Village, L'ile aux Images, 1986.

Morton, A. G., History of Botanical Science, an account of the development of Botany from ancient times to the present day. London, Academic Press, 1981.

Moura, A. R., "Sobre os vandaus (Sofala - Moçambique)", in Moçambique: aspectos da cultura material. Coimbra, Instituto de Antropologia, Universidade de Coimbra, 1986, pp. 55-76, fig. 1-44 (Publicações do Centro de Estudos Africanos, 6).

Moura, A. R., "Contribuição para o conhecimento da cestaria de Moçambique", in Cestaria tradicional em África. Coimbra, Instituto de Antropologia, Universidade de Coimbra, 1988, pp. 13-34, fig. 1-64 (Publicações do Centro de Estudos Africanos, 9).

Natividade, J. V., "A flora da lírica de Camões", Memórias da Academia das Ciências de Lisboa 14 (1970), pp. 7-63.

Orta, Garcia de, Coloquios dos simples e drogas da India. Ed. Academia Real das Sciencias de Lisboa (dirigida e anotada por Conde de FicalHo) I. Lisboa, 1891.

Orta, Garcia de, Coloquios dos simples e drogas da India. Ed. Academia Real das Sciencias de Lisboa (dirigida e anotada por Conde de Ficalho) II. Lisboa, 1895.

PAIVA, J., “Jardins Botânicos. Sua origem e importância”, Munda 2 (1981), pp. 35-44. 
Reynolds, G. W., The Aloes of South Africa. Johannesburg, Aloes of South Africa Book Fund, 1950.

Reynolds, G. W., The Aloes of Tropical Africa and Madagascar. Mbabane, The Trustees. The Aloes Book Fund, 1966.

Santos, C. A. dos, "Camóes y Góngora; una lectura del erotismo en Los Lusíadas y en la Fábula de Polifemo y Galatea", Castilla. Estudios de Literatura 28-29 (2003-2004), pp. 23-46.

Saraiva, J. H., Vida ignorada de Camões. Mem Martins, Publicações Europa-América, 1982 (Estudos, Ensaios e Documentos 141).

Sonnerat, Pierre, Voyage a la Nouvelle Guinée. Paris, Ruault, 1776.

Ventura, A. F. G., “As Flores Hiacintinas de Camóes”, O Instituto 75 (1928), pp. 397-408.

Ventura, A. F. G., "O Adónis de Camóes" (Miscelânea de estudos em honra de D. Carolina Michaëlis de Vasconcelos), Revista da Universidade de Coimbra 11 (1933), pp 1009-1016.

Ventura, A. F. G., "Subsídio para o estudo da Flora Camoneana. III- A Viola”, O Instituto 83, 12 (1932), pp. 344-354.

Ventura, A. F. G., "Subsídio para o estudo da Flora Camoneana. IV- Boninas e rosas", Biblos 9 (1933), pp.128-138.

Ventura, A. F. G., "Subsídio para o estudo da Flora Camoneana. V- Lírios e legação", O Instituto 85 (1933), pp. 180-185.

Ventura, A. F. G., "Subsídio para o estudo da Flora Camoneana. VI- O Bácaro e o louro", Biblos 11 (1935), pp.72-84.

Ventura, A. F. G., "Subsídio para o estudo da Flora Camoneana. VII- Fruta da Ilha dos Amores", Biblos 12 (1936), pp. 212-222.

Ventura, A. F. G., "O Côco da barca do Purgatório de Gil Vicente e o Jasmim dos Lusíadas e da Lírica de Camôes”, Liceus de Portugal 29 (1943), pp. 2329-2334.

Ventura, A. F. G., "Notas Camonianas", Brasilia 4 (1949), pp. 119-154.

Ventura, A. F. G., "Notas Camonianas", Brasilia 10 (1958), pp. 1- 37.

Ventura, A. F. G., "Notas Camonianas”, Brasilia 11 (1961), pp. 1-29.

Vidago, João, "Ilha de Santa Helena, Ilha dos Amores, Escala da "Carreira da Índia" (1502-1625)", Boletim da Sociedade de Geografia de Lisboa, Série 94a , n.os 7-, 10-12 (1976), pp. 153-175.

Tavares, C. N., "Os Lusíadas e a Botânica”, Garcia de Orta, N.o Especial (1972), pp. 547-567. 
A partir dos alvores do século XVI, a matéria médica torna-se indiscutivelmente um tema de primeira grandeza entre os membros da República das Letras, objecto de estudo e de controvérsia entre os mais notáveis humanistas europeus, em particular entre os cultores da arte médica. Entre os autores em destaque neste volume encontram-se, à cabeça, os nomes de Amato Lusitano, Garcia de Orta e Nicolás Monardes, famosos pelos contributos valiosos que deram para o conhecimento do mundo natural. 0 volume encontra-se dividido em duas partes: a primeira, subordinada ao título "Humanismo e Ciência", alberga os estudos que versam sobre todos os autores estudados, à excepção de Amato Lusitano; a segunda está reservada a um conjunto de trabalhos dedicados exclusivamente ao médico albicastrense, cuja autoria se fica a dever, em boa parte, aos membros da equipa do projecto de I\&D "Dioscórides e o Humanismo Português: os Comentários de Amato Lusitano", tomando, por isso, 0 seu próprio título. Nesta segunda parte, oferece-se, desde já, aos leitores uma amostra significativa do trabalho desenvolvido no âmbito do projecto e que culminará, assim se espera, na edição e tradução integral para língua portuguesa das quatro obras previstas de Dioscórides, Amato Lusitano e Pietro Andrea Mattioli. 
